\title{
Late Pleistocene-Holocene amphibians from Okinawajima Island in the Ryukyu Archipelago, Japan: Reconfirmed faunal endemicity and the Holocene range collapse of forest-dwelling species
}

\author{
Yasuyuki Nakamura and Hidetoshi Ota
}

\begin{abstract}
Amphibian fossils excavated from two Late Pleistocene-Holocene fissures in the southern part of Okinawajima Island in the Ryukyu Archipelago were identified through detailed comparisons with skeletal specimens of extant taxa. The identified species (eight frogs and two newts) were confined to extant elements on the island and were mostly endemic to either the island or the central part of the archipelago including it. Previous Late Pleistocene records of extralimital frogs (two mainland Japanese species [Glandirana rugosa and Rana tagol] and one Southeast Asian frog currently naturalized in the Ryukyus [Polypedates leucomystax]) from one of the study sites (the Minatogawa Fissure) are therefore considered misidentifications. This may also be the case with Fejervarya kawamurai, a synanthropic frog currently widely distributed in East Asia, including the Central Ryukyus. Of the species obtained from the Late Pleistocene deposits at these sites, five frogs (Limnonectes namiyei, Babina holsti, Odorrana ishikawae, $O$. narina, and Rana ulma) are forest-dwellers currently confined to the northern forested area of Okinawajima. Additionally, none of these species were detected in the middle Holocene deposits from one of the sites, the Sashiki Fissure. Our findings indicate that the southern limestone area of Okinawajima in the Late Pleistocene harbored a dense and humid forest with diverse lotic habitats, similar to the northern forested area of the island at present, and that these environmental conditions were lost by the midpoint of the Holocene Period.
\end{abstract}

Yasuyuki Nakamura. Tropical Biosphere Research Center, University of the Ryukyus, Senbaru 1, Nishihara, Okinawa 903-0213, Japan. ynaka.riukiaria@gmail.com

Hidetoshi Ota. Institute of Natural and Environmental Sciences, University of Hyogo, and the Museum of Nature and Human Activities, Yayoi-gaoka 6, Sanda, Hyogo 669-1546, Japan. ohta@hitohaku.jp

Keywords: Biogeography; frogs; limestone; newts; paleoenvironment

PE Article Number: 18.1.1A

Copyright: Palaeontological Association January 2015

Submission: 6 August 2014. Acceptance: 19 December 2014

Nakamura, Yasuyuki and Ota, Hidetoshi. 2015. Late Pleistocene-Holocene amphibians from Okinawajima Island in the Ryukyu Archipelago, Japan: Reconfirmed faunal endemicity and the Holocene range collapse of forest-dwelling species. Palaeontologia Electronica 18.1.1A: 1-26.

palaeo-electronica.org/content/2015/935-okinawan-amphibians 


\section{INTRODUCTION}

Original anthropological excavation at the Minatogawa Fissure on Okinawajima Island of the Ryukyu Archipelago from 1968 to 1974 resulted in the discovery of a number of Late Pleistocene human bones (Kaifu and Fujita, 2012; and literature cited therein) and numerous associated remains of other terrestrial vertebrates (e.g., Hasegawa, 1980; Kawamura, 1989; Matsuoka, 2000). The amphibian fossil assemblage was reported to contain a total of 10 or 11 (if "Rhacophorus sp." was counted) anurans and one newt species (Hasegawa, 1980). However, the assemblage has often been regarded as unusual because the presence of some of the component species exhibited an obvious discrepancy with a biogeographers' view of the archipelago and the intrinsic characteristics of the Pleistocene limestone substrate of the southern part of the island, where the fissure is located (e.g., Ota, 2003).

From the biogeographical viewpoint, the fossil occurrence of two ranid species (Wrinkled Frog Glandirana rugosa and Tago's Brown Frog Rana tagoi) known only from mainland Japan and adjacent islets (Maeda and Matsui, 1999; Frost, 2014) remarkably contradict the highly endemic nature of the current terrestrial vertebrate fauna of the Central Ryukyus (i.e., the Amami and Okinawa Island Groups and some nearby islands). This current state unequivocally reflects the long-standing isolation of this region from nearby landmasses, particularly the more northern areas of Japan (e.g., Okada and Koba, 1931; Ota, 1998; Matsui, 2005; Motokawa, 2009). Indeed, the extant indigenous amphibian fauna of the Central Ryukyus (11 out of 14 species are endemic) does not share its component species with mainland Japan, except for the Marsh Frog Fejervarya kawamurai (formerly known as Rana or Fejervarya limnocharis), a widely distributed dicroglossid frog that ranges from Honshu (mainland Japan) through the Central Ryukyus and Taiwan to Central-South China (Djong et al., 2011). To explain the biogeographical peculiarity of the Central Ryukyu populations, some researchers argue that the species reached this location through relatively recent oversea dispersals from the Eurasian Continent (Toda et al., 1997; Toda, 1999) (see Discussion).

From a paleoenvironmental perspective, the fossil occurrence of five obligate forest-dwelling frog species (Namiye's Frog Limnonectes namiyei, Holst's Frog Babina holsti, Ishikawa's Frog Odorrana ishikawae, Okinawa Tip-nosed Frog $O$. narina, and Ryukyu Brown Frog Rana ulma) that are currently strictly confined to the northern forested hilly area of the island is astonishing (Ota, 2003). This is because the habitat requirements of these frogs (dense forest for adults and shallow streams under forest cover for juvenile growth; e.g., Utsunomiya et al., 1983) are quite incompatible with the inherent properties of the Pleistocene limestone substrate that predominates in the southern part of Okinawajima - high porosity (Maekado, 1989) and karstic topography, which can absorb surface freshwater habitats (Nishijima et al., 1974; Tachihara, 2003). In fact, the southern part of the island, particularly the limestone areas, lack such lotic habitats and therefore the four extant frogs and two newts in the region (Fejervarya kawamurai, Ryukyu Narrow-mouthed Toad Microhyla okinavensis, Ryukyu Kajika Frog Buergeria japonica, Okinawa Green Tree Frog Rhacophorus viridis viridis, Sword-tailed Newt Cynops ensicauda, and Anderson's Crocodile Newt Echinotriton andersoni) are mostly lentic breeders.

Hasegawa (1980) left several questions unanswered because he simply listed the taxa identified in the Minatogawa Fissure without providing information to verify his species identification. In addition, the lack of a follow-up study has prevented us from ascertaining the exact state of the Late Pleistocene amphibian fauna of the island as well as its biogeographical/paleoenvironmental significance. Here we report on Late Quaternary amphibian fossils recovered from two limestone fissures located in the southern limestone area of Okinawajima. One of the sites is the Minatogawa Fissure, which was recently re-excavated in an anthropological survey. Both of the limestone fissures yielded an abundance of Late Pleistocene amphibian fossils, and middle Holocene amphibian remains were discovered at one of the sites. These fossils are adequate to document snapshots of Late Quaternary local amphibian fauna and provide information about changes in the paleoenvironmental conditions in the area.

\section{MATERIAL AND METHODS}

\section{Geological Settings}

Okinawajima (ca. $1200 \mathrm{~km}^{2}$ ) is a narrow island oriented on a NE-SW axis with a maximum length of $100 \mathrm{~km}$ (Figure 1). The island consists of two geologically contrastive components: the northern part is comprised mainly of pre-Neogene strata (e.g., Fujita, 1989) and the southern part is composed of the Plio-Pleistocene Shimajiri Group (siltstone associated with tuff), Pleistocene Chinen 


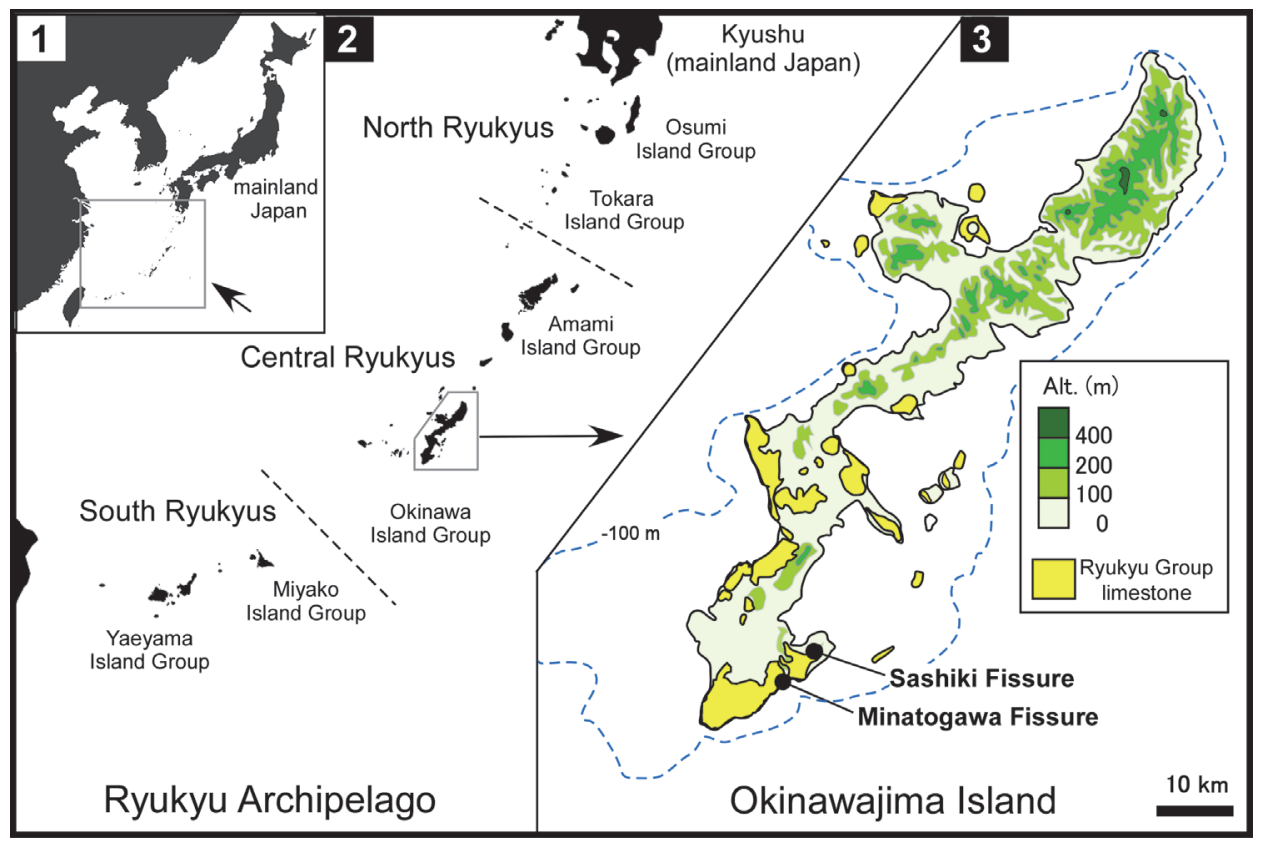

FIGURE 1. Maps of the Ryukyu Archipelago $(\mathbf{1}, \mathbf{2})$ and Okinawajima Island (3). The map of Okinawajima shows topography, distribution of the Pleistocene limestone, and study sites. Geological data were obtained from Kizaki (1985).

Formation (calcareous sandstone and sandy limestone), and Pleistocene Ryukyu Group limestone (e.g., Sagae et al., 2012). The Ryukyu Group distributed in the southern part is divided into three sections: the Itoman Formation (Early Pleistocene), Naha Formation (Early to Middle Pleistocene), and Minatogawa Formation (presumably Late Pleistocene) (see Sagae et al., 2012).

\section{Study Sites}

The amphibian fossils examined here were derived from two limestone fissures located in the southern part of Okinawajima Island (Figure 1).

Minatogawa Fissure $\left(26^{\circ} 07^{\prime} 46^{\prime \prime} \mathrm{N}, 127^{\circ} 45^{\prime} 34^{\prime \prime}\right.$ E; elevation: $20 \mathrm{~m}$ a.s.I). The Minatogawa Fissure in Nagamou, Yaese Town, is located on a bank of the Yuhi River $(0.5 \mathrm{~km}$ from the mouth of the river), on the southeastern coast of the island. It is a crevice formed in the Minatogawa Formation of the Ryukyu Group (e.g., Tsuchi, 1982). As mentioned above, Hasegawa (1980) reported 11 or 12 species of amphibians and their relative quantities (Table). Of these, Glandirana rugosa (as Rana rugosa) and Rana tagoi are known as mainland Japanese species and there is no other record from the island or the Central Ryukyus (see above). Additionally, Nokariya (1983b) mentioned the fossil occurrence of Polypedates leucomystax (as Rhacophorus leucomystax), a Southeast Asian rhacophorine frog believed to have been introduced to the Ryukyus in the mid-20th century (see Discussion); presumably this frog corresponds to "Rhacophorus sp." in Hasegawa (1980). Although we were unable to examine the amphibian fossils discussed by Hasegawa (1980) and Nokariya (1983b), we investigated unsorted fossils collected in the recent (1998-2001) anthropological excavation at the fissure (see Hashimoto et al., 2002 for details). These fossils were collected by water screening. Part of the fossils were reported to contain one vertebra of Limnonectes namiyei, one right ilium of Babina holsti, one vertebra of Odorrana narina, 41 miscellaneous bones of unidentified anurans, and $79 \mathrm{precaudal} / \mathrm{caudal}$ vertebrae of unidentified newts (Nohara and Irei, 2002). However, we did not confirm these records except for $B$. holsti because most of the fossils discussed by Nohara and Irei (2002) could not be identified (presumably, they are included in the studied material).

The age of the Minatogawa fossils examined here is estimated as the latest Late Pleistocene. An Accelerator Mass Spectrometry (AMS) ${ }^{14} \mathrm{C}$ age of $13,460 \pm 110$ BP (ca. 15,670 cal. BP: calibrated using Fairbanks0107 [Fairbanks et al., 2005]) was reported by Hashimoto et al. (2002) for a sample of sediment humates from deposits located at the base of the fissure, from which all the amphibian fossils were derived. The fossils examined here 
TABLE. Amphibian taxa and abundance (in minimum number of individuals [MNI]) from two Late Pleistocene-Holocene fissures in Okinawajima, and a comparison with the results of Hasegawa (1980). - indicates absence of the fossil, * denotes extralimital taxa (mainland Japanese species: Glandirana rugosa and Rana tagoi; Southeast Asian species: Polypedates leucomystax), and ** denotes a taxon mentioned by Nokariya (1983b).

\begin{tabular}{|c|c|c|c|c|}
\hline \multirow[t]{3}{*}{ Species } & \multirow{3}{*}{$\begin{array}{c}\text { Hasegawa (1980) } \\
\text { Minatogawa Fissure } \\
\text { (Late Pleistocene) }\end{array}$} & \multicolumn{3}{|c|}{ This study } \\
\hline & & \multirow{2}{*}{$\begin{array}{c}\text { Minatogawa Fissure } \\
\text { (Late Pleistocene) }\end{array}$} & \multicolumn{2}{|c|}{ Sashiki Fissure } \\
\hline & & & $\begin{array}{c}\text { Lower unit } \\
\text { (Late Pleistocene) }\end{array}$ & $\begin{array}{c}\text { Upper unit } \\
\text { (middle Holocene) }\end{array}$ \\
\hline \multicolumn{5}{|l|}{ Anura } \\
\hline Fejervarya kawamurai & "rare" & - & - & - \\
\hline Limnonectes namiyei & "rare" & 1 & 1 & - \\
\hline Babina holsti & "rare" & 2 & 6 & - \\
\hline Glandirana rugosa* & "abundant" & - & - & - \\
\hline Odorrana ishikawae & "common" & - & 7 & - \\
\hline O. narina & "abundant" & 40 & 5 & - \\
\hline Rana tagoi* & "rare" & - & - & - \\
\hline R. ulma & "abundant" & 49 & 152 & - \\
\hline Microhyla okinavensis & "rare" & - & - & 2 \\
\hline Buergeria japonica & - & 1 & - & 1 \\
\hline Rhacophorus viridis viridis & "rare" & 1 & 6 & 1 \\
\hline $\begin{array}{l}\text { Rhacophorus sp. (or Polypedates } \\
\text { leucomystax* }{ }^{\star \star}\end{array}$ & "rare" & - & - & - \\
\hline \multicolumn{5}{|l|}{ Caudata } \\
\hline Cynops ensicauda & "common" & 20 & 51 & 1 \\
\hline Echinotriton andersoni & - & 1 & 92 & - \\
\hline
\end{tabular}

are housed at the Yaese Town Museum of History and Folklore, Yaese Town, Okinawa Prefecture, Japan (YMHF-MA; we provisionally assigned the abbreviation for the institution and the collection number).

Sashiki Fissure $\left(26^{\circ} 09^{\prime}\right.$ 82" N, $127^{\circ} 48^{\prime} 32$ ' E; elevation: $160 \mathrm{~m}$ a.s.I.). The Sashiki Fissure (Moriguchi, 2003; "Chinen Fissure" in Azuma, 2007) in Sashiki-Tedokon, Nanjo City, lies ca. 6 km northeast of the Minatogawa Fissure (Figure 1) and is situated on an uplifted terrace of the Naha Formation on the Chinen Peninsula. This fissure is a sinkhole (ca. $8 \mathrm{~m}$ in depth) that was exposed by limestone mining (Figure 2). Our excavation at the fissure was conducted from 2004-2008. Because the remnant infill consisted of two discrete components, we treated the sediments separately as follows: the "lower unit" formed at the base and the "upper unit" deposited on a shelf (Figure 2). Our effort for stratigraphic control at the excavation site was limited due to the infill, particularly in the lower unit, which had collapsed and was largely exposed. Fossils were gathered using dry or wet screening (1 $\mathrm{mm}$ mesh). Some of the fossils were collected by Mr. Mitsuru Moriguchi and courteously provided for this study.

The sediments of the lower unit had a height of approximately $2.2 \mathrm{~m}$ and were composed of dark brown clayey soil with limestone debris. The exact amount of the sediments we examined is unknown, but it was at least double the amount of the upper unit (see below). Most of the fossils from the lower unit have been dated to the Late Pleistocene because a fragment of charcoal collected $1 \mathrm{~m}$ from the bottom produced an AMS ${ }^{14} \mathrm{C}$ age of $31,745 \pm$ 216 cal. BP (Conventional Radiocarbon Age: $26,480 \pm 150 \mathrm{BP} ; \delta{ }^{13} \mathrm{C}$ [measured using AMS]: $27.96 \pm 0.89 \%$; sample number: IAAA-80231; cali- 


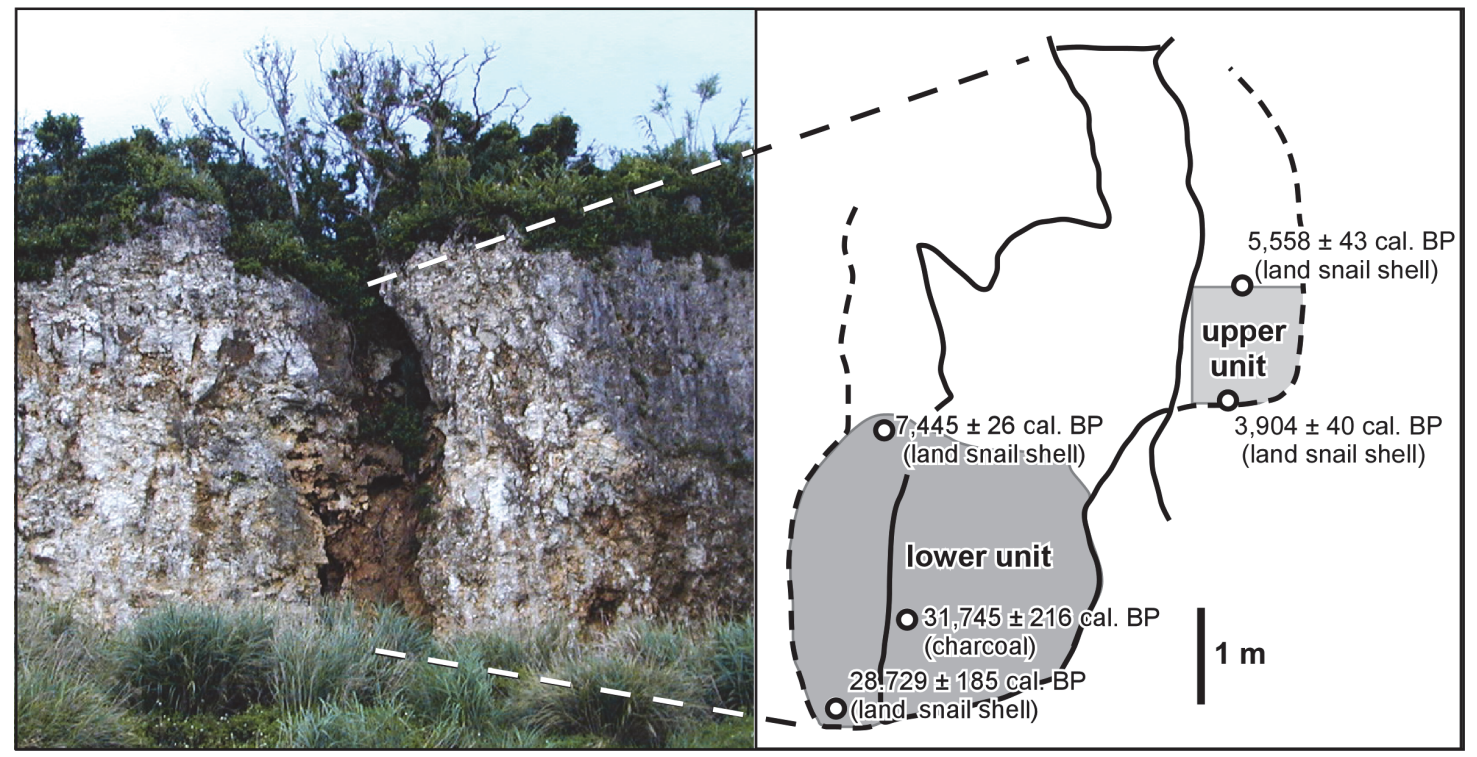

FIGURE 2. Photograph of the Sashiki Fissure (left) and schematic figure showing the structure of the fissure (right). In the right figure, broken lines represent the outline of the fissure behind rock, shaded areas represent studied sediments, and open circles represent the locations of the dating samples.

bration curve used: Fairbanks0107, same hereafter; this and the following radiometric dates were measured by the Institute of Accelerator Analysis Ltd. [IAA], Kawasaki, Japan). However, a land snail (Cyclophorus turgidus) shell from the bottom of the sediment yielded a relatively younger age of $28,729 \pm 185$ cal. BP $(24,000 \pm 120$ BP; $-7.21 \pm$ $0.46 \%$; IAAA-80228). A C. turgidus shell from the top of the remnant sediments of the unit $(2.2 \mathrm{~m}$ from the bottom) yielded an AMS ${ }^{14} \mathrm{C}$ age of 7,445 \pm 26 cal. BP $(6,540 \pm 40 \mathrm{BP} ;-8.52 \pm 0.62 \%$; IAAA80227 ), but no vertebrate fossils were discovered in this area of the sediments. These somewhat inverted estimates suggest that the matrix may have been disturbed, but could partially be explained by the difference in the chemical properties of the dating samples (i.e., terrestrial plant and land snail shell) or by sample pollution from modern carbonate. Although the sediments lack any sign of human occupation, the inferred depositional ages postdate human arrival on the island (prior to 37 ka; Kaifu and Fujita, 2012). Additionally, Azuma (2007) reported a radiocarbon age of the fissure deposits of 22,941 \pm 434 cal. BP, using Cyclophorus shells presumably derived from this unit, but the details of the dating are uncertain.

The fossils obtained from the fissure, which were presumably derived from the lower unit sediments defined here, included terrestrial crabs, land snails, and some vertebrates (Moriguchi, 2003; Naruse et al., 2004; Azuma, 2007). We also recov- ered a metacarpal fragment of the extinct Ryukyu Deer Cervus astylodon and numerous fossils of the Okinawa Spiny Rat Tokudaia muenninki, the Amami Woodcock Scolopax mira, and the Okinawa Rail Gallirallus okinawae, which are not currently found on this part of the island. Those remains were derived from various sized animals, and small vertebrates including amphibians were mostly represented by several parts of cranial and postcranial skeletons. Thus, these fossils, together with those obtained from the upper unit (see below), may suggest that the fissure acted as a pitfall for small animals and a sink for surface debris.

The upper unit sediments were comprised of approximately $0.4 \mathrm{~m}^{3}(1 \mathrm{~m}$ high, $1 \mathrm{~m}$ deep, and 0.4 $\mathrm{m}$ wide) of light brown clayey soil on the floor of the shelf (Figure 2). The AMS ${ }^{14} \mathrm{C}$ ages of Cyclophorus turgidus shells derived from the bottom $(3,904 \pm 40$ cal. BP $[3,600 \pm 30 \mathrm{BP} ;-9.26 \pm 0.32 \%$; IAAA$80229])$ and the top $(5,558 \pm 43 \mathrm{cal}$. BP $[4,810 \pm 40$ BP; $-10.42 \pm 0.87 \%$; IAAA-80230]) generally fall within the range of the middle Holocene. As in the case of the lower unit, these inverted estimates suggest that there was some disturbance of the matrix or pollution of the samples.

In contrast with the lower unit, the sediments of the upper unit produced a number of different marine fish bones that may be interpreted as leavings of early human inhabitants (although such remains may have been left by roosting seabirds, such as ospreys or boobies). However, neither arti- 
facts nor present-day debris were discovered. There were also several fossils of other vertebrates, particularly those that are presently absent in the southern part of the island, such as the Ryukyu Long-furred Rat Diplothrix legata. We therefore regarded the fossils from the unit as being representative middle Holocene fauna, presumably associated with early civilization. The amphibian fossils from this fissure are located in the Fujukan, University Museum of the University of the Ryukyus, Nishihara Town, Okinawa Prefecture, Japan (RUMF).

\section{Identification}

A common limitation of accuracy in the identification of amphibian fossils lies in the frequent insufficiency of characters for the phylogenetic analysis that can be extracted from available bone fragments. Therefore, as practiced in some previous studies on the Quaternary paleoherpetology, our identification was based on overall similarity through direct comparisons with the skeletal specimens of extant taxa. We used specimens representing all extant anuran species of Japan (except Glandirana susurra, which is confined to an offshore island of northern Honshu [Sekiya et al., 2012]) and of all three salamander (newt) species known from the Ryukyu Archipelago (Appendix). Specimens of other extant anurans and salamanders from adjacent areas, such as those from Korean Peninsula, were also examined. Additionally, literature information on the osteology of Japanese anurans (Nokariya, 1983a, b, 1984) was consulted. Because all fossils were from relatively recent geological ages (see above), present geographic distributions of the extant taxa were considered in selecting the comparative materials, and we believe possible effect of such an a-priori assumption on the accuracy in identification is negligibly small.

We concentrated our identification of anuran fossils on the humeri and ilia, which are dominant elements in the fossils discussed here and are useful for species-level identification. Morphological comparisons were conducted using a binocular microscope (Nikon SMZ-10). The minimum number of individuals (MNI) was calculated for each taxon from each site/excavation unit. Osteological terminology follows Bolkay $(1919,1933)$ and Sanchiz (1998) for anurans, and Estes (1981) and Duellman and Trueb (1986) for salamanders. The higher group taxonomy of amphibians follows that of Frost (2014).

\section{SYSTEMATIC PALEONTOLOGY}

Class AMPHIBIA de Blainville, 1816

Order ANURA Fischer von Waldheim, 1813

Family DICROGLOSSIDAE Anderson, 1871

Genus LIMNONECTES Fitzinger, 1843

Limnonectes namiyei (Stejneger, 1901)—Namiye's

Frog

Figure 3.1-3.4

Occurrence (MNI). Minatogawa: 1; Sashiki (lower unit): 1.

Referred material. Minatogawa: 1 female humerus (left: YMHF-MA 001); Sashiki (lower unit): 1 ilium (left: RUMF-GF-04000).

Humerus. A left humerus lacking the proximal part of the shaft, the distal half of the distal condylar part, and the crista ventralis (YMHF-MA 001: Figure $3.1-3.3$ ), is referred to this large-sized frog. The identification is based on the absence of the crista medialis and the crista lateralis, and the possession of a stout and scarcely waisted shaft, a massive distal condylar part, a well-concaved fossula dividens, a very weak spina tuberculi medialis (sensu Bolkay [1919, p. 330-331], which refers to a ridge on the shaft extending distally from the tuberculum mediale of the caput humeri), and a pointed proximal tip of the olecranon scar (in dorsal view). The gender (female) is inferred from the slender overall shape. Practical observations on the humerus of this species by Nokariya (1984) are confined to the presence of the fossula dividens and the crista paraventralis (the crest was mistakenly referred to as the "spina tuberculi medialis" in his publication; see Nokariya and Hasegawa [1979, figure 2]).

Ilium. A left ilium lacking the anterior part of the ilial shaft (RUMF-GF-04000: Figure 3.4) is referred to this species. Nokariya's (1984) observations on the ilium of this species note a well-developed crista dorsalis and the tuber superior that is separated from the acetabular margin. The following combination of character states may be useful to discriminate the ilium from those of other Japanese anurans examined: a thin, high (the height [from the ventral edge of the ilial shaft, same hereafter] is higher than that of the acetabulum), and anteriorly tapered crista dorsalis with an angulated posterodorsal corner; a straight posterior edge of the crista dorsalis that forms at a sharp angle with the anterior edge of the pars ascendens; the tuber superior that is mediolaterally thin, subround in shape, and defined by a weakly ridged margin; a straight anterior edge of the pars ascendens; and a distinct supracetabular fossa. 


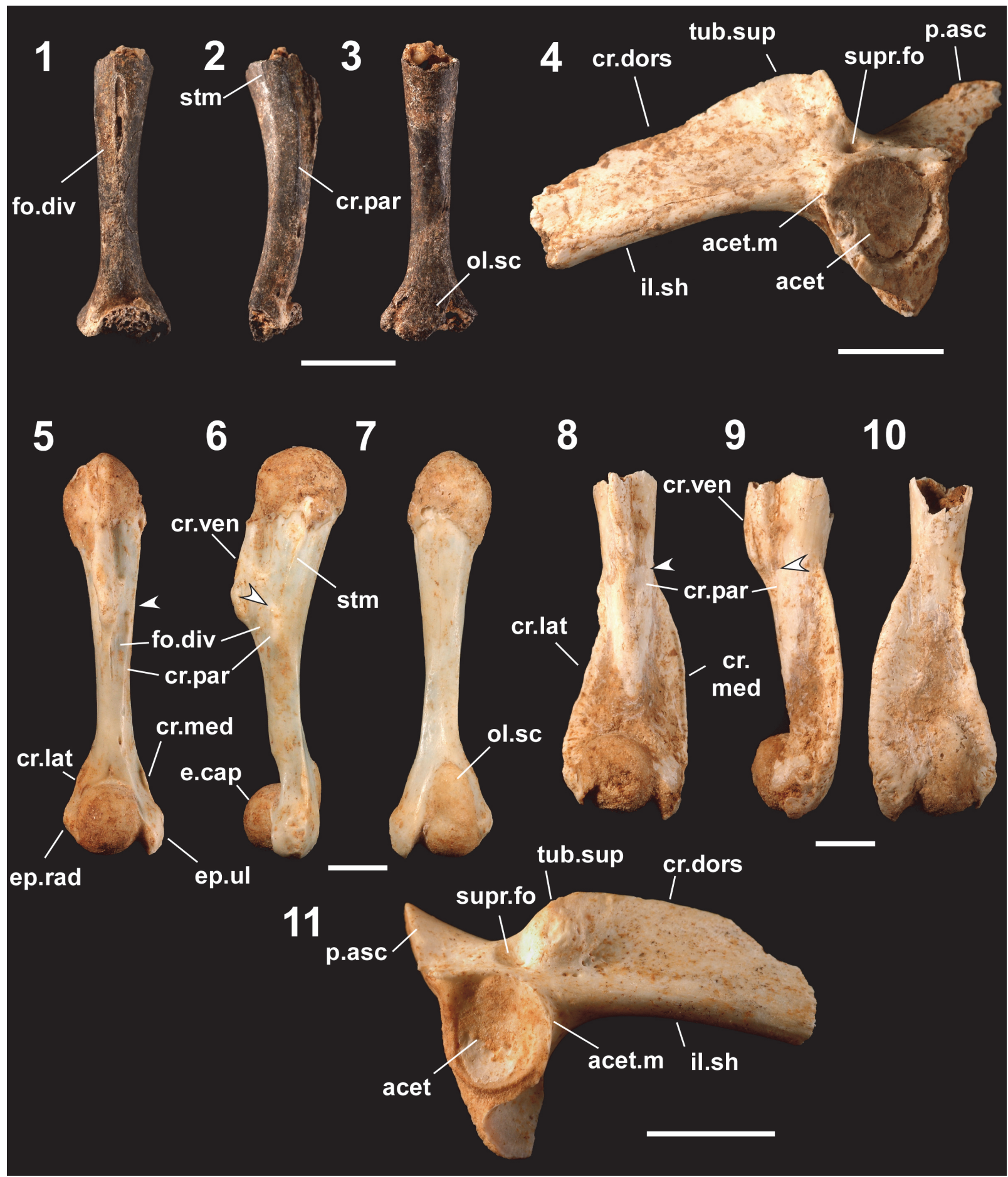

FIGURE 3. Fossils referred to Limnonectes namiyei (1-4) and Babina holsti (5-11). 1-3, left female humerus lacking the proximal and distal parts and the crista ventralis (YMHF-MA 001) in ventral (1), medial (2) and dorsal (3) views; 4, left ilium lacking the anterior part (RUMF-GF-04000) in lateral view; 5-7, right female humerus (one of six registered as RUMF-GF-04003) in ventral (5), medial (6) and dorsal (7) views; 8-10, right male humerus lacking the proximal part (one of two registered as RUMF-GF-04004) in ventral (8), medial (9), and dorsal (10) views; and 11, right ilium lacking the anterior part (one of nine registered as RUMF-GF-04005) in lateral view. Abbreviations: acet, acetabulum; acet.m, acetabular margin; cr.dors, crista dorsalis; cr.lat, crista lateralis; cr.med, crista medialis; cr.par, crista paraventralis; cr.ven, crista ventralis; e.cap, eminentia capitata; ep.rad, epicondylus radialis; ep.ul, epicondylus ulnaris; fo.div, fossula dividens; il.sh, ilial shaft; ol.sc, olecranon scar; p.asc, pars ascendens; stm, spina tuberculi medialis; supr.fo, supracetabular fossa; tub.sup, tuber superior. Scale bars equal $5 \mathrm{~mm}$. 
Family RANIDAE Rafinesque, 1814

Genus BABINA Thompson, 1912

Babina holsti (Boulenger, 1892)—Holst's Frog

Figure 3.5-3.11

Occurrence (MNI). Minatogawa: 2; Sashiki (lower unit): 6 .

Referred material. Minatogawa: 2 female humeri (right: YMHF-MA 002) and 2 ilia (right: YMHF-MA 003); Sashiki (lower unit): 6 female humeri (1 right and 5 left: RUMF-GF-04003), 2 male humeri (1 right and 1 left: RUMF-GF-04004), and 9 ilia (6 right and 3 left: RUMF-GF-04005).

Humerus. Nokariya's (1984) observations on the humerus of this large-sized frog note a laterally projected epicondylus radialis, a small and ridgelike crista lateralis (female only), and a proximally positioned waisted part of the shaft (female only). The other diagnostically useful character states of the humerus are: a robust and strongly waisted shaft; a high crista ventralis with a straight ventral edge that is parallel to the dorsal edge of the shaft (in mediolateral views); the distal edge of the crista ventralis that forms an oblique angle with the ventral outline of the shaft (in mediolateral views); the distance between the ventrodistal corner of the crista ventralis and the eminentia capitata, which is only 2.5 times longer than the length of the eminentia capitata; the crista paraventralis that extends proximally to the level of the ventrodistal corner of the crista ventralis; the proximal part of the epicondylus ulnaris that protrudes medially (more than the distal part in dorsoventral views); and a tapered and round outline of the proximal part of the olecranon scar (in dorsal view). The crista lateralis and the crista medialis of male humeri inflect dorsally, with the former extending laterally beyond the level of the lateral edge of the epicondylus radialis, and the latter extending medially beyond the level of the medial edge of the epicondylus ulnaris (Figure 3.8-3.10). These crests are ridge-like in the female (Figure 3.5-3.7) and extend proximally to the level of the crista ventralis forming angulated ridges of the shaft (as a consequence, the cross-section of the narrowest part of the shaft forms a semicircle). The fossula dividens scarcely concaves in the female and some males while it concaves deeply in some males; and the spina tuberculi medialis is weak in the female and some males, but developed in other males (Figure 3.8-3.10).

Ilium. Nokariya's (1984) observations on the ilium of this species note a well-developed crista dorsalis and tuber superior. The other diagnostic combinations of the character states on the ilium (Figure
3.11) are: an elliptical and swell-like tuber superior without ridging in the margin; the tuber superior that is in contact with the acetabular margin (contra Nokariya, 1984); a thin and high (the height is higher than that of the acetabulum) crista dorsalis with a gently round posterodorsal corner; the pars ascendens with a posteriorly curved anterior edge; and a distinct supracetabular fossa.

Remarks. While the ilia and female humeri of this species are morphologically indistinguishable from those of Babina subaspera (the sibling species endemic to the Amami Island Group: Maeda and Matsui, 1999), fossils of these elements are referred on the basis of the species' exclusive occurrence on the island. Male humeri of $B$. holsti differ from those of $B$. subaspera by having lessdeveloped crista lateralis and crista medialis.

Genus ODORRANA Fei, Ye, and Huang, 1990

Odorrana ishikawae (Stejneger, 1901)—Ishikawa's Frog

Figure 4.1-4.7

Occurrence (MNI). Sashiki (lower unit): 7.

Referred material. 10 female humeri (5 right and 5 left: RUMF-GF-04009), 3 male humeri (2 right and 1 left: RUMF-GF-04010), and 5 ilia (4 right and 1 left: RUMF-GF-04011).

Humerus. The humerus of this large-sized frog (Figure 4.1-4.6) differs from those of other anurans examined (except $O$. splendida, see below) in having a series of character states: a robust shaft that is strongly waisted at the point proximal to the condylar part (in dorsoventral views); a weakly curved ventral edge of the crista ventralis, which is not parallel to the dorsal margin of the shaft (in mediolateral views); the distal edge of the crista ventralis that forms an oblique angle with the ventral outline of the shaft (in mediolateral views); a distinct crista paraventralis that extends proximally beyond the level of the ventrodistal corner of the crista ventralis; a developed spina tuberculi medialis; a depressed and flattened shaft at the area intervening between the spina tuberculi medialis and the crista ventralis; a usually distinct and shallowly concaved fossula dividens; a scarcely protruded epicondylus radialis; the distal part of the epicondylus ulnaris that protrudes medially (more than the proximal part in dorsoventral views); and a gently round outline of the proximal part of the olecranon scar (in dorsal view). In the female, the crista medialis and the crista lateralis are ridge-like (Figure $4.1,4.3$ ), while in the male, the former is developed but the medial extent is less than the level of the medial edge of the epicondylus ulnaris, and the latter is much less developed than the former with a 


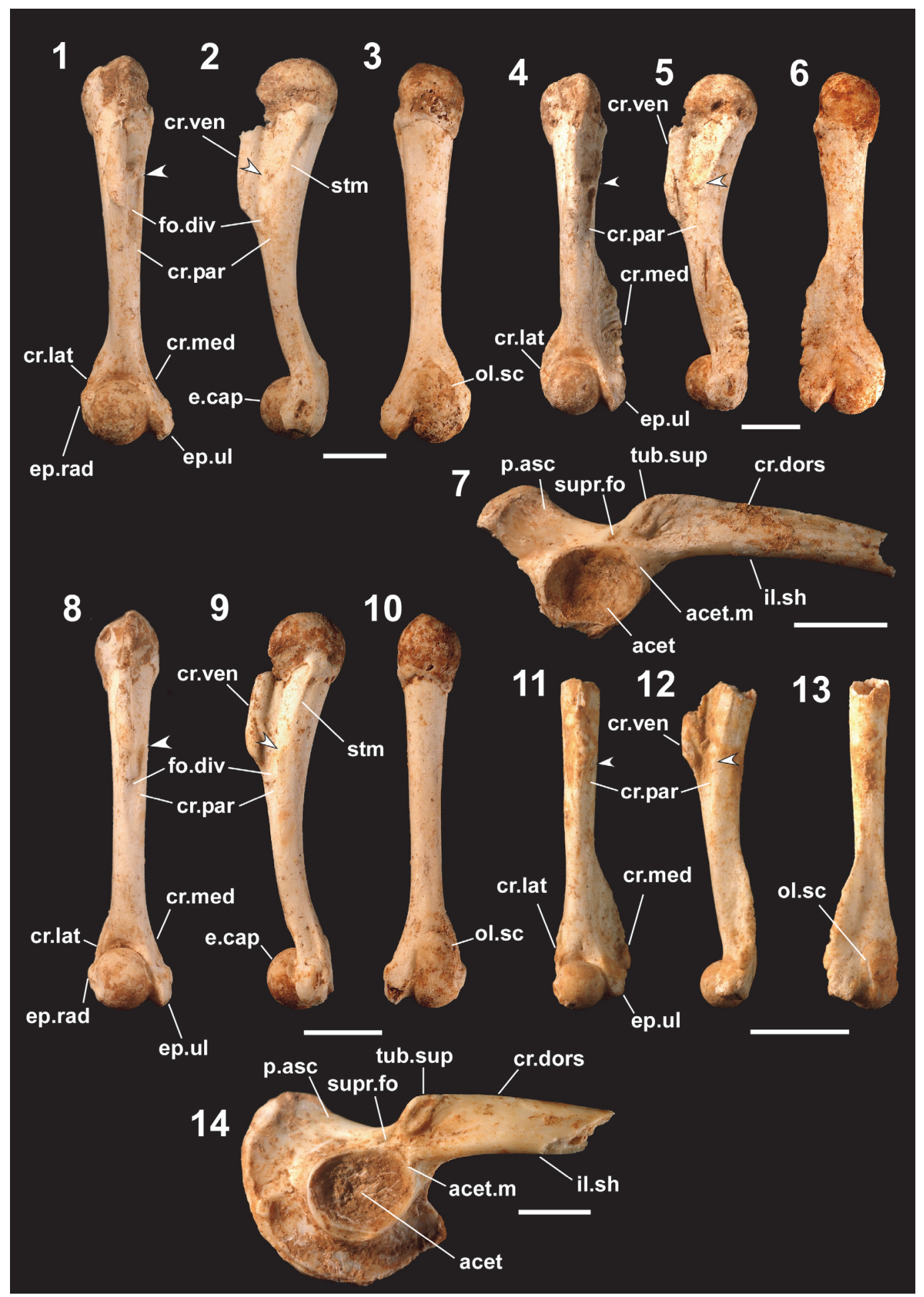

FIGURE 4. Fossils referred to Odorrana ishikawae (1-7) and Odorrana narina (8-14), 1-3, right female humerus (one of 10 registered as RUMF-GF-04009) in ventral (1), medial (2), and dorsal (3) views; 4-6, right male humerus (one of three registered as RUMF-GF-04010) in ventral (4), medial (5), and dorsal (6) views; 7, right ilium lacking the anterior part with part of the ischium (one of five registered as RUMF-GF-04011) in lateral view; 8-10, right female humerus (one of eight registered as RUMF-GF-04014) in ventral (8), medial (9), and dorsal (10) views; 11-13, right male humerus lacking the proximal part of the shaft and the distal part of the epicondylus ulnaris (RUMF-GF-04015) in ventral (11), medial (12), and dorsal (13) views; and 14, pelvic girdle (fused right and left ilia [lacking anterior parts] with the ischium and the pubis: RUMF-GF-04016) in right lateral view. Abbreviations are the same as Figure 3. Arrows indicate the proximal ends of the crista paraventralis. Scale bars equal $5 \mathrm{~mm}$. 
laterally convex edge (Figure 4.4, 4.6). Nokariya (1984) did not provide useful observations on the humerus of this species.

Ilium. The ilium of this species (Figure 4.7) differs from that of the other anurans examined (except $O$. splendida) in having a series of character states: the tuber superior that is separated from the acetabular margin (Nokariya, 1984); a comma shaped tuber superior that is usually anteroposteriorly longer than the height with a gently curved posterodorsal corner; a ridged margin of the tuber superior; a thick and low crista dorsalis (the height is less than that of the acetabulum); the crista dorsalis that is anteriorly tapered with a straight dorsal edge; a medial inclination of the crista dorsalis, except the posterior end; the pars ascendens with a posteriorly curved anterior edge; and a fused supracetabular fossa.

Remarks. The Amamioshima Island (Amami Island Group) population of this species has been described as O. splendida (see Kuramoto et al., 2011). These sibling species resemble each other osteologically, while $O$. ishikawae has more robust humeri and a more developed crista medialis in male humeri. The species-level identification of the fossil ilia discussed here is based on the species' exclusive occurrence on the island.

\section{Odorrana narina (Stejneger, 1901)_Okinawa Tip- nosed Frog \\ Figure 4.8-4.14}

Occurrence (MNI). Minatogawa: 40; Sashiki (lower unit): 5.

Referred material. Minatogawa: 45 female humeri (21 right and 24 left: YMHF-MA 004), 32 male humeri (16 right and 16 left: YMHF-MA 005), and 53 ilia (22 right and 31 left: YMHF-MA 006); Sashiki (lower unit): 8 female humeri (4 right and 4 left: RUMF-GF-04014), 1 male humerus (right: RUMF-GF-04015), 1 pelvic girdle (RUMF-GF04016), and 1 ilium (left: RUMF-GF-04017).

Humerus. The humerus of this middle-sized frog (Figure 4.8-4.13) can be distinguished from that of other anurans examined (except allied species, see below) by having a series of character states: a slender shaft with an almost uniform diameter throughout the length; a straight ventral edge of the crista ventralis that is often nearly parallel to the dorsal edge of the shaft (in mediolateral views); the distal edge of the crista ventralis that forms an oblique angle with the ventral outline of the shaft (in mediolateral views); a distinct crista paraventralis that extends proximally to the level of the ventrodistal corner of the crista ventralis; a weak spina tubercli medialis; a distinct and shallowly concaved fossula dividens; a scarcely protruded epicondylus radialis; the proximal part of the epicondylus ulnaris that protrudes medially (more than the distal part in dorsoventral views); and a gently round outline of the proximal part of the olecranon scar (in dorsal view). The crista medialis and the crista lateralis are fringe-like in the female (Figure 4.8, 4.10), while in the male, the former extends medially beyond the level of the medial edge of the epicondylus ulnaris, and the latter forms a straightedged ridge of the shaft (Figure 4.11, 4.13). Nokariya (1984) did not provide useful observations on the humerus of this species.

Ilium. Nokariya (1984) noted that the tuber superior of this species is separated from the acetabular margin. Other informative character states on the ilium (Figure 4.14) are: the tuber superior that is well-defined and encircled by a ridged margin; a parallelogram- or drop-shaped tuber superior with a weakly angulated posterodorsal corner and straight, steep posterior edge; the tuber superior that is higher than the anteroposterior length; the crista dorsalis that is thick, low (the height is less than that of the acetabulum), and weakly tapered anteriorly with a straight dorsal edge; a medial inclination of the crista dorsalis (except the posterior end); the pars ascendens with a posteriorly curved anterior edge; and a fused supracetabular fossa.

Remarks. It is difficult to discriminate the humerus and the ilium of $O$. narina from those of allied species of the Ryukyus (O. amamiensis, $O$. supranarina, and $O$. utsunomiyaorum) based solely on the morphological characters. The species-level identification of the fossils discussed here is based on the species' exclusive occurrence on the island.

Genus RANA Linnaeus, 1758

Rana ulma Matsui, 2011 (formerly known as $R$. okinavana Boettger, 1895: see Matsui, 2007)— Ryukyu Brown Frog Figure 5.1-5.7

Occurrence (MNI). Minatogawa: 49; Sashiki (lower unit): 152.

Referred material. Minatogawa: 89 female humeri (41 right and 48 left: YMHF-MA 007), 1 male humerus (left: YMHF-MA 008), and 17 ilia (8 right and 9 left: YMHF-MA 009); Sashiki (lower unit): 176 female humeri (108 right and 68 left: RUMFGF-04019), 87 male humeri (44 right and 43 left: RUMF-GF-04020), and 93 ilia (46 right and 47 left: RUMF-GF-04021).

Humerus. Correct observations on the humerus of this tiny, slender-bodied frog by Nokariya (1984; as Rana [Rana] okinavana) are confined to a weak crista paraventralis and a distinct fossula dividens. 


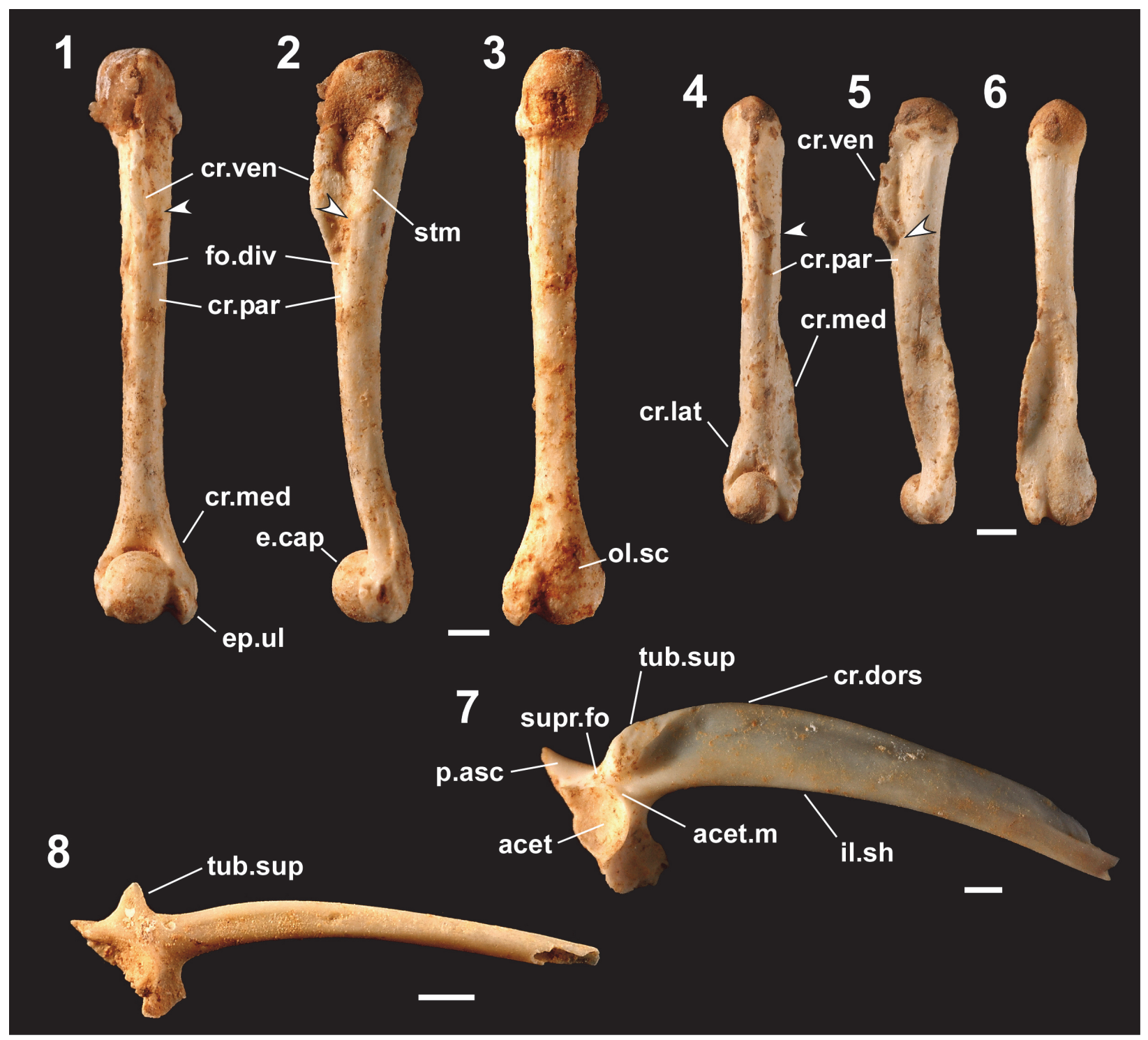

FIGURE 5. Fossils referred to Rana ulma (1-7) and Microhyla okinavensis (8). 1-3, right female humerus (one of 176 registered as RUMF-GF-04019) in ventral (1), medial (2), and dorsal (3) views; 4-6, right male humerus (one of 87 registered as RUMF-GF-04020) in ventral (4), medial (5), and dorsal (6) views; 7, right ilium (one of 93 registered as RUMF-GF-04021) in lateral view; and 8, right ilium (one of two registered as RUMF-GF-04023) in lateral view. Abbreviations are the same as Figure 3. Arrows indicate the proximal ends of the crista paraventralis. Scale bars equal 1 $\mathrm{mm}$.

The humerus of this species (Figure 5.1-5.6) may be identified on the basis of having a series of character states (see also below): a slender and nearly straight shaft with an almost uniform diameter throughout the length; a proximodistally short crista ventralis (the distance between the ventrodistal corner and the eminentia capitata is at least 4.5 times longer than the length of the eminentia capitata); a straight ventral edge of the crista ventralis that is nearly parallel to the dorsal edge of the shaft (in mediolateral views); the distal edge of the crista ventralis that forms an oblique angle with the ventral outline of the shaft (in mediolateral views); the crista paraventralis that extends proximally to the level of the ventrodistal corner of the crista ventralis; a distinct spina tuberculi medialis; a scarcely protruded epicondylus radialis; the distal part of the epicondylus ulnaris that usually protrudes medially (more than the proximal part in dorsoventral views); and a tapered and pointed proximal part of the olecranon scar (in dorsal view). Female humeri usually lack the crista medialis and the crista later- 
alis, but some show a fringe-like crista medialis (Figure 5.1-5.3). In male humeri, a well-developed crista medialis extends proximally to the midpoint of the shaft, while the proximal extent of the crista lateralis is more confined (Figure 5.4-5.6).

llium. The ilium of this species (Figure 5.7) can be diagnosed on the basis of having a series of character states (see also below): a spindle- or commashaped tuber superior, which is in contact with, or separated from, the acetabular margin (contra Nokariya, 1984); a thin and moderately high crista dorsalis, the height of which is almost the same as that of the acetabulum (Nokariya, 1984); a gently arched dorsal edge of the crista dorsalis, which is highest at the point much anterior to the tuber superior; a posteriorly curved anterior edge of the pars ascendens; and an open supracetabular fossa.

Remarks. The humerus of this species is morphologically similar to those of closely related species, $R$. kobai (endemic to the Amami Island Group) and $R$. tsushimensis (endemic to Tsushima Island, north of Kyushu); the ilium is also similar to that of $R$. kobai. The fossils discussed here are referred to $R$. ulma on the basis of the exclusive occurrence on the island.

Family MICROHYLIDAE Günther, 1858 (1843)

Genus MICROHYLA Tschudi, 1838

Microhyla okinavensis Stejneger, 1901 (formerly

known as $M$. ornata Duméril and Bibron, 1841: see

Matsui et al., 2005)—Okinawa Narrow-mouthed Toad

Figure 5.8

Occurrence (MNI). Sashiki (upper unit): 2.

Referred material. 2 ilia (right: RUMF-GF-04023). Ilium. The referred ilia (Figure 5.8) of this tiny toad are distinguished from those of the other Japanese anurans on the basis of the lack of the crista dorsalis and the possession of a dorsally-protruded, conical-shaped tuber superior (Nokariya, 1983a; Nakamura et al., 2009).

Family RHACOPHORIDAE Hoffman, 1932 (1858) Subfamily BUERGERIINAE Channing, 1989

Genus BUERGERIA Tschudi, 1838

Buergeria japonica (Hallowell, 1861)—Ryukyu Kajika Frog

Figure 6.1-6.4

Occurrence (MNI). Minatogawa: 1; Sashiki (upper unit): 1.

Referred material. Minatogawa: 1 female humerus (right: YMHF-MA 010); Sashiki (upper unit): 1 ilium (left: RUMF-GF-04024).
Humerus. The female humerus of this tiny frog (Figure 6.1-6.3) is unique among Japanese anurans in having a combination of character states: an indistinct olecranon scar (Nokariya, 1983b), an angulated medial margin of the proximal part of the epicondylus ulnaris (in dorsoventral views) (Nokariya, 1983b), a short epicondylus ulnaris that does not reach the level of the distal tip of the eminentia capitata (Nokariya, 1983b), a mediolaterally widened shaft at the part proximal to the eminentia capitata, a ventrally-oriented and fringe-like crista medialis and crista lateralis, and the proximal part of the epicondylus ulnaris that protrudes medially (more than the distal part in dorsoventral views). The male humeri differ from those of females in having better developed crista medialis and crista lateralis (contra Nokariya, 1983b).

Ilium. The following character states differentiate the ilium (Figure 6.4) from that of the other anurans examined: a narrow preacetabular zone (Nokariya, 1983b); the tuber superior that is in contact with the acetabular margin (Nokariya, 1983b); an elliptical tuber superior that is much higher than the length; a moderately high crista dorsalis (the height is almost the same as that of the acetabulum) with a uniform height across most of the length (most of the crest was lost in the referred specimen: Figure 6.4); a laterally overhanging posterior part of the crista dorsalis; an angulated posterodorsal corner of the crista dorsalis; a posteriorly curved anterior edge of the pars ascendens; and an indistinct supracetabular fossa (see also Nakamura et al., 2009).

Subfamily RHACOPHORINAE Hoffman, 1932 (1858)

Genus RHACOPHORUS Kuhl and Van Hasselt, 1822

Rhacophorus viridis viridis (Hallowell, 1861) Okinawa Green Tree Frog

Figure 6.5-6.11

Occurrence (MNI). Minatogawa: 1; Sashiki (lower unit): 6 , (upper unit): 1.

Referred material. Minatogawa: 2 gender unknown humeri (1 right and 1 left: YMHF-MA 011); Sashiki (lower unit): 7 female humeri (2 right and 5 left: RUMF-GF-04025), 1 gender unknown humerus (left: RUMF-GF-04026), 1 ilium (right: RUMF-GF-04028), and 1 pelvic girdle (RUMF-GF04029); Sashiki (upper unit): 1 male humerus (left: RUMF-GF-04027).

Humerus. These middle-sized slender humeri (Figure 6.5-6.10) can readily be referred to rhacophorine genera (e.g., Kurixalus, Polypedates, and Rhacophorus) on the basis of having a developed 


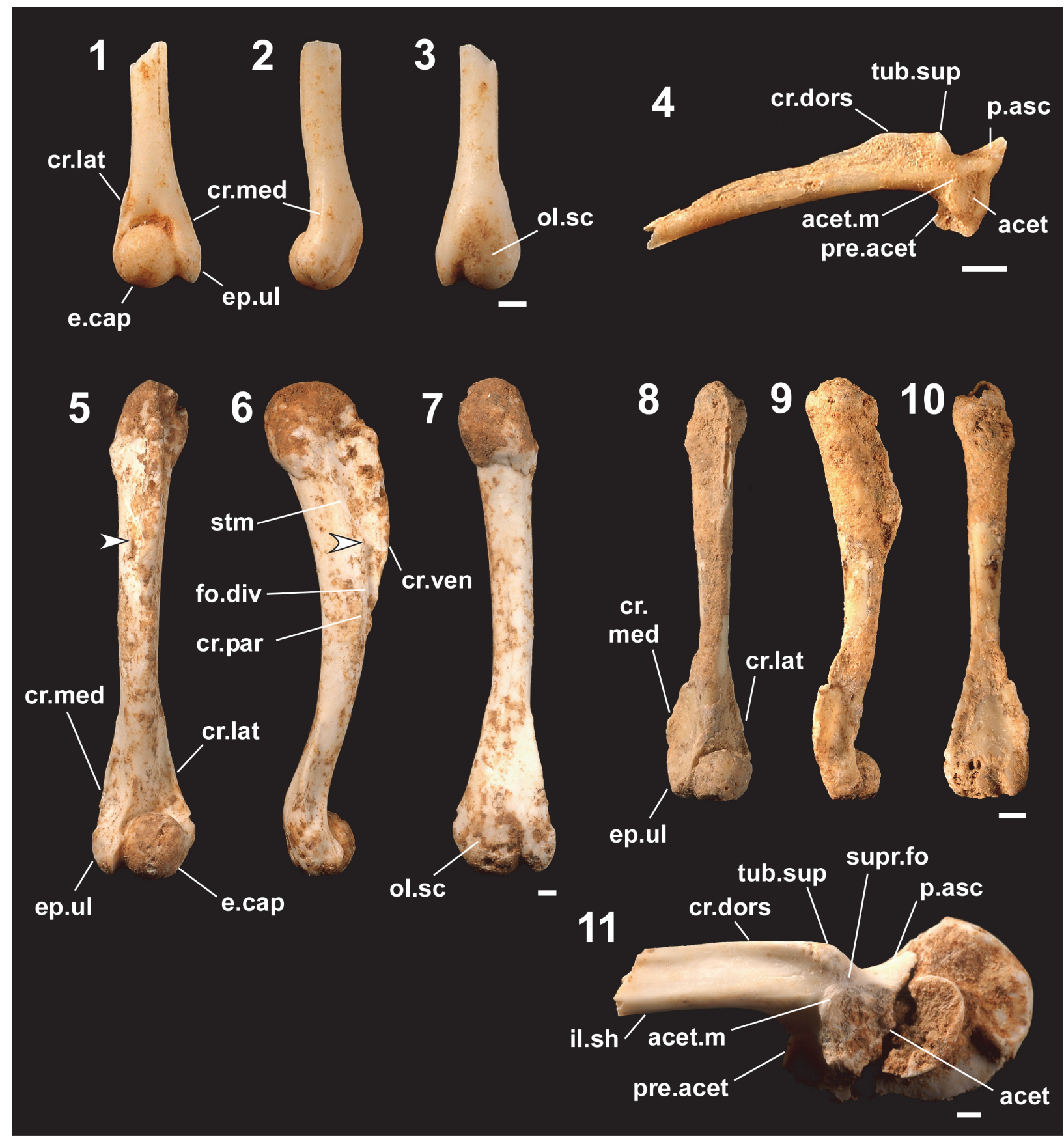

FIGURE 6. Fossils referred to Buergeria japonica (1-4) and Rhacophorus viridis viridis (5-11). 1-3, right female humerus lacking the proximal part (YMHF-MA 010) in ventral (1), medial (2), and dorsal (3) views; 4, left ilium lacking most part of the crista dorsalis (RUMF-GF-04024) in lateral view; 5-7, left female humerus (one of seven registered as RUMF-GF-04025) in ventral (5), medial (6), and dorsal (7) views; 8-10, left male humerus (RUMF-GF-04027) in ventral (8), medial (9), and dorsal (10) views; and 11, pelvic girdle (fused right and left ilia [lacking anterior parts] with the ischium: RUMF-GF-04029) in left lateral view. Abbreviations: pre.acet, preacetabular zone; the others are the same as Figure 3. Arrows indicate the proximal ends of the crista paraventralis. Scale bars equal $1 \mathrm{~mm}$. 
crista medialis and crista lateralis; a slender shaft with a mediolaterally thin proximal part; an indistinct olecranon scar; a gently curved ventral and distal edges of the crista ventralis (in mediolateral views); the distal edge of the crista ventralis that meets at a slight angle to the ventral outline of the shaft (in mediolateral views); and a small and proximodistally elongated eminentia capitata (Nokariya, 1983b).

The fossil humeri resemble those of Rhacophorus viridis, the only indigenous rhacophorine species in the Central Ryukyus, and differ from those of Polypedates leucomystax (a rhacophorine species naturalized in the Ryukyus: see above) in having a crista ventralis that extends distally to almost the midpoint of the shaft (vs. usually confined to one-third of the shaft: Nokariya, 1983b) and male's crista medialis that extends medially beyond the level of the medial edge of the epicondylus ulnaris (vs. less-developed). The gender of the fossil humeri was inferred from the developmental degree of the crista lateralis and the crista medialis (Nokariya, 1983b).

Ilium. The fossil ilia (Figure 6.11) are referred to rhacophorine frogs on the basis of having a wide preacetabular zone (Nokariya, 1983b), a small and tubercle-like tuber superior, a thick and low crista dorsalis (the height is much less than that of the acetabulum), and a nearly fused supracetabular fossa. They resemble those of $R h$. viridis and differ from those of $P$. leucomystax in having a tuber superior that is separated from the acetabular margin (vs. contact: Nokariya, 1983b) and a straight dorsal margin of the crista dorsalis that is in parallel with the ventral margin of the ilial shaft (vs. a posteriorly sloping posterior part of the crest: Nakamura et al., 2009).

Remarks. Currently, two subspecies are recognized under Rhacophorus viridis (Maeda and Matsui, 1999). The fossils are referred to $R h$. viridis viridis on the basis of the exclusive occurrence on the island.

Order CAUDATA Fischer von Waldheim, 1813

Family SALAMANDRIDAE Goldfuss, 1820 Genus CYNOPS Tschudi, 1838

Cynops ensicauda (Hallowell, 1861)—Sword-tailed Newt

Figure 7

Occurrence (MNI). Minatogawa: 20; Sashiki (lower unit): 51, (upper unit): 1.

Referred material. Minatogawa: 8 atlantes (YMHF-MA 012), 32+ postatlantal precaudal vertebrae (YMHF-MA 013), 35 humeri (20 right and 15 left: YMHF-MA 014), and 23 femora (11 right and
12 left: YMHF-MA 015); Sashiki (lower unit): 3 maxillae (2 right and 1 left: RUMF-GF-04032), 1 parietal-prootic-exoccipital (RUMF-GF-04033), 1 frontal (left: RUMF-GF-04035), 2 squamosals (right: RUMF-GF-04036), 9 dentaries (6 right and 3 left: RUMF-GF-04037), 5 atlantes (RUMF-GF04038), 108 postatlantal precaudal vertebrae (RUMF-GF-04039), 25 ribs (14 right and 11 left: RUMF-GF-04040), 85 humeri (41 right and 44 left: RUMF-GF-04041), and 92 femora (51 right and 41 left: RUMF-GF-04042); Sashiki (upper unit): 1 maxilla (right: RUMF-GF-04043) and 3 postatlantal precaudal vertebrae (RUMF-GF-04044).

Axial skeletons. The referred postatlantal precaudal vertebrae (Figure 7.1-7.4) are referred to salamandrid newts in having an opisthocoelous centrum and a high neural spine (as opposed to an amphicoelous centrum and a low and flattened neural spine in cryptobranchids and hynobiids [Estes, 1981; Venczel, 1999], the other Caudata known from Japan). They differ from those of Echinotriton andersoni (the other salamandrid newt of the Central Ryukyus) in having a smooth dorsal surface of the horizontal plate at the top of the neural spine; zygapophyses that position dorsal to the diapophyses; a round condyle with a precondylar constriction; and laminae that fringe anterior margins of the parapophyses (see also below). They resemble those of Cynops ensicauda, and differ from those of the mainland Japanese congener $C$. pyrrhogaster in having an anteroposteriorly flattened (vs. less flattened) condyle and a strong (vs. weak) precondylar constriction. The atlantes (Figure $7.5,7.6$ ) are referred to this species on the basis of morphological differences from that of syntopic $E$. andersoni: less-developed crests on lateral sides of the neural arch and the lack of extensive dermal ossification on the dorsal surface of the neural spine (see below).

Cranial and postcranial skeletons. The other elements are referred to the species on the basis of several morphological differences from those of $E$. andersoni (see also below): the lack of an extensive dermal sculpturing in several cranial elements (frontal, squamosals, parietal-prootic-exoccipital [Figure 7.7], and maxillae [Figure 7.8]); a maxilla with a relatively short, posteriorly broadened, and dorsally turned posterior process (also differs from that of $C$. pyrrhogaster with a more short posterior process); a delicate dentary (Figure 7.9) with a medially exposed anterior subdental ditch and a notch for the prearticular that extends anteriorly to the midpoint of the bone; a truncate rib (Figure 7.10) with a single knob-like epipleural process; a 


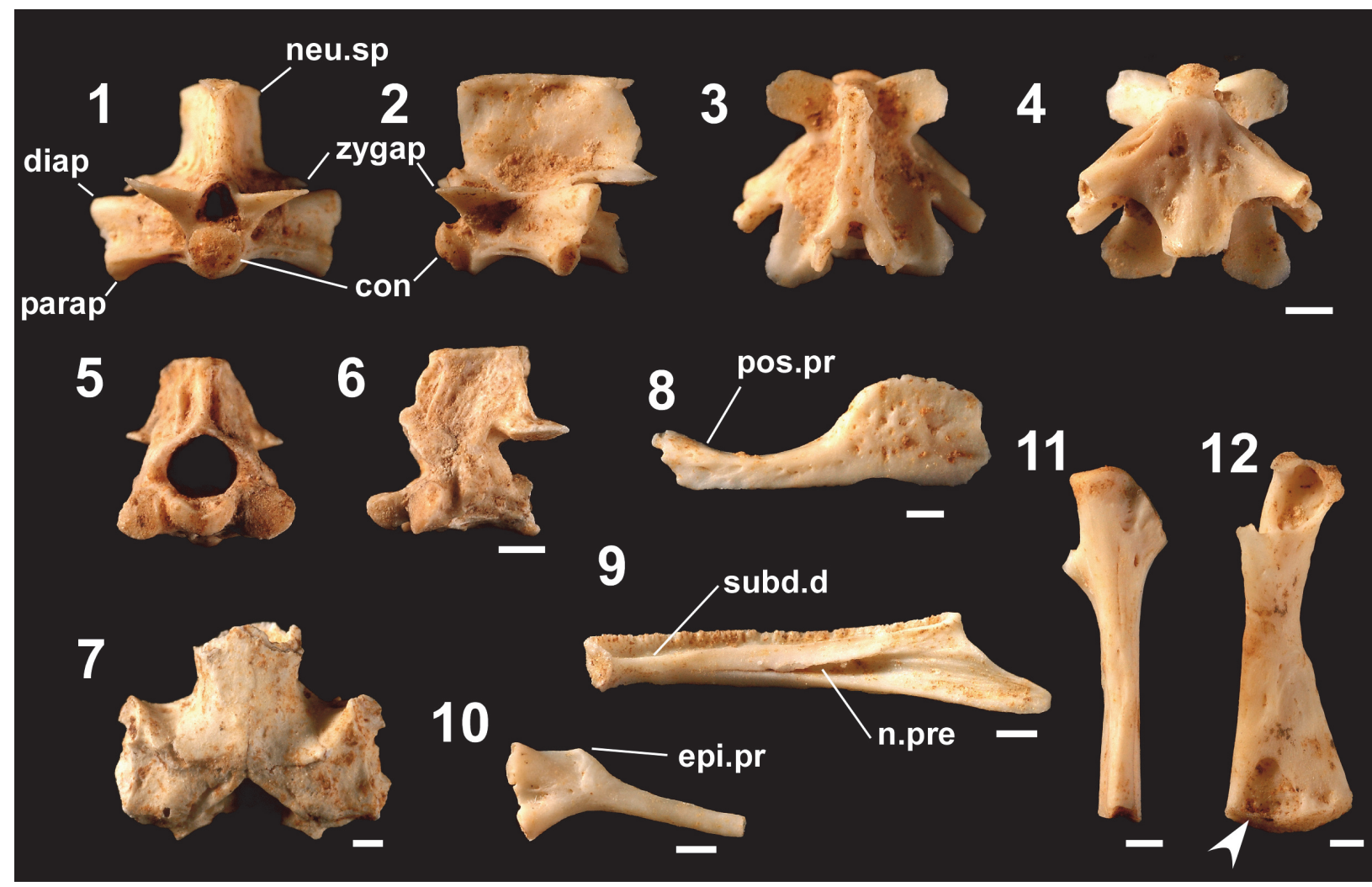

FIGURE 7. Fossils referred to Cynops ensicauda. 1-4, postatlantal precaudal vertebra (one of 108 registered as RUMF-GF-04039) in anterior (1), left lateral (2), dorsal (3), and ventral (4) views; 5 and 6, atlas (one of five registered as RUMF-GF-04038) in anterior (5) and left lateral (6) views; 7, parietal-prootic-exoccipital (RUMF-GF-04033) in dorsal view; 8, right maxilla (one of three registered as RUMF-GF-04032) in lateral view; 9, right dentary (one of nine registered as RUMF-GF-04037) in medial view; 10, right rib (one of 25 registered as RUMF-GF-04040) in posterior view; 11, right humerus (one of 85 registered as RUMF-GF-04041) in lateral view; and 12, right femur (one of 92 registered as RUMF-GF-04042) in posterior view. Abbreviations: con, condyle; diap, diapophyses; epi.pr, epipleural processes; neu.sp, neural spine; n.prep, notch for prearticular; parap, parapophyses; pos.pr, posterior process; subd.d, subdental ditch; zygap, zygapophyses. The arrow in 12 indicates the concavity (see text). Scale bars equal $1 \mathrm{~mm}$.

straight and slender humerus (Figure 7.11) with a thin and angulated radial margin; and a stout femur (Figure 7.12) with a concavity at the distal part of the flexor surface of the fibular condyle (indicated by an arrow).

Genus ECHINOTRITON Nussbaum and Brodie,
1982

Echinotriton andersoni (Boulenger, 1892)Anderson's Crocodile Newt Figure 8

Occurrence (MNI). Minatogawa: 1; Sashiki (lower unit): 92.

Referred material. Minatogawa: 3 postatlantal precaudal vertebrae (YMHF-MA 016) and 1 femur (right: YMHF-MA 017); Sashiki (lower unit): 30 maxillae (11 right and 19 left: RUMF-GF-04045), 13 frontals (7 right and 6 left: RUMF-GF-04046), 1 parietal-prootic-exoccipital (RUMF-GF-04047), 18 squamosals (9 right and 9 left: RUMF-GF-04048), 5 quadrates (3 right and 2 left: RUMF-GF-04049), 70 dentaries (28 right and 42 left: RUMF-GF04050), 11 atlantes (RUMF-GF-04051), 290 postatlantal precaudal vertebrae (RUMF-GF04052), 181 ribs (89 right and 92 left: RUMF-GF04053), 144 humeri (68 right and 76 left: RUMFGF-04054), and 163 femora (71 right and 92 left: RUMF-GF-04055).

Axial skeletons. Referred postatlantal precaudal vertebrae (Figure 8.1-8.4) differ from those of cryptobranchids and hynobiids in having an opisthocoelous centrum and a high neural spine, and from those of Cynops examined in having a heavily sculptured horizontal dermal plate on the neural spine (also seen in atlantes: Figure 8.5, 8.6); the zygapophyses that position below the level of the dorsal edges of the diapophyses (except the axis and the sacrum); a massive and laterally wide con- 


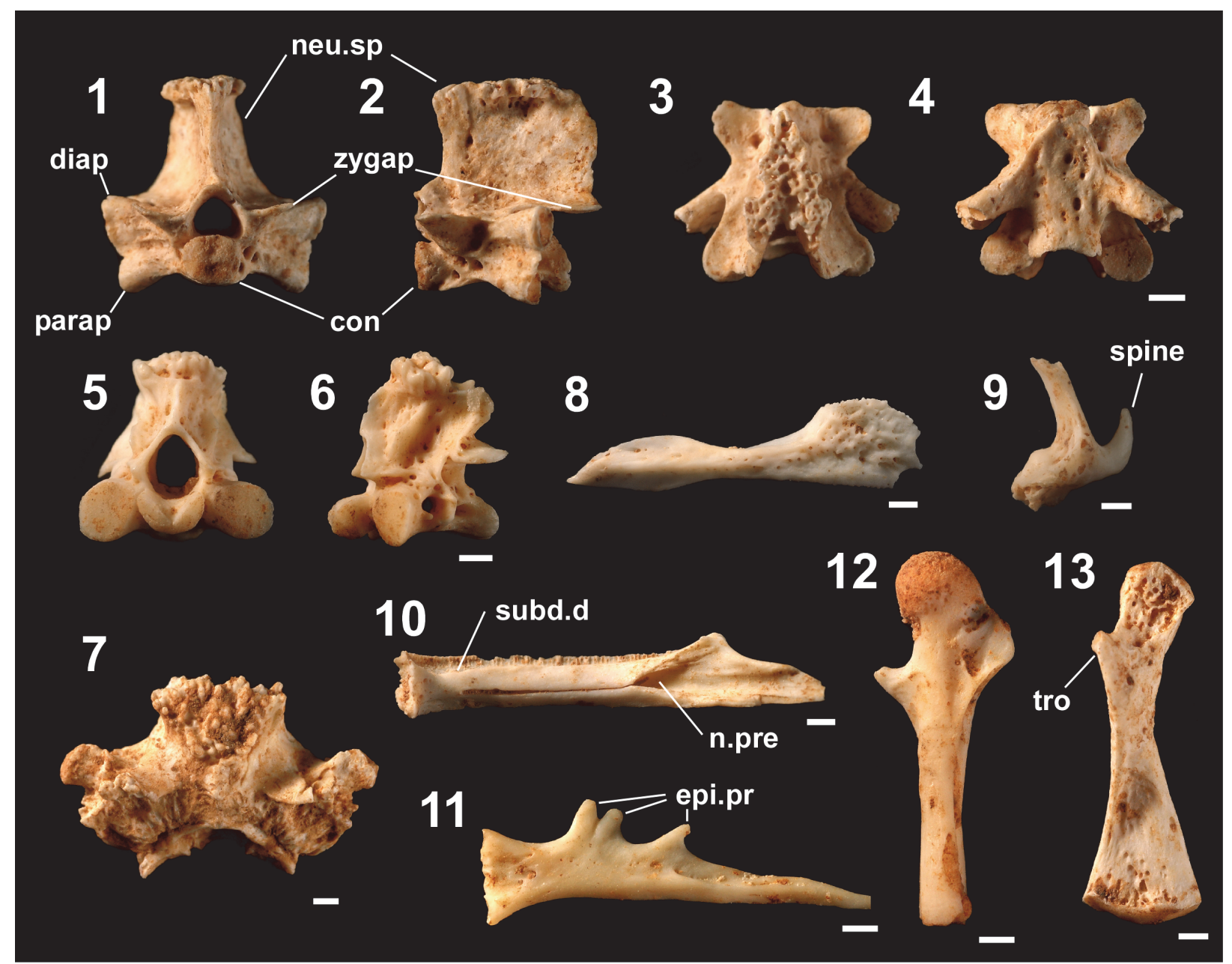

FIGURE 8. Fossils referred to Echinotriton andersoni. 1-4, postatlantal precaudal vertebra (one of 290 registered as RUMF-GF-04052) in anterior (1), left lateral (2), dorsal (3), and ventral (4) views; 5 and 6, atlas (one of 11 registered as RUMF-GF-04051) in anterior (5) and left lateral (6) views; 7, parietal-prootic-exoccipital (RUMF-GF-04047) in dorsal view; 8, right maxilla (one of 30 registered as RUMF-GF-04045) in lateral view; 9, right quadrate (one of five registered as RUMF-GF-04049) in dorsal view; 10, right dentary (one of 70 registered as RUMF-GF-04050) in medial view; 11, right rib (one of 181 registered as RUMF-GF-04053) in posterior view; 12, right humerus (one of 144 registered as RUMF-GF-04054) in lateral view; and 13, right femur (one of 163 registered as RUMF-GF-04055) in posterior view. Abbreviations: tro, trochanter; the others are the same as Figure 7 . Scale bars equal $1 \mathrm{~mm}$.

dyle without precondylar constriction; and the parapophyses without fringing laminae at the anterior margins (except the sacrum and a few presacral vertebrae). The referred atlantes differ from those of Cynops in having developed crests on the lateral sides of the neural arch.

Cranial and postcranial skeletons. The fossil specimens of the parietal-prootic-exoccipital (Figure 8.7), maxillae (Figure 8.8), and frontals are referred to this species on the basis of having an extensive dermal ossification with numerous pits, which is a diagnostic feature of Echinotriton and the related Tylototriton (see Estes, 1981). Likewise, the quadrate (Figure 8.9) with a distinct spine on the posterodistal corner (an Echinotriton synapomorphy: Nussbaum and Brodie, 1982; Cai and Fei, 1984) and the pointed rib (Figure 8.11) with 0-4 spine-like and dorsally projecting epipleural processes ( $>1$ processes is a unique character state seen in E. andersoni: Nussbaum and Brodie, 1982) confirm the taxonomic allocation.

Several other elements of referred specimens differ from those of syntopic C. ensicauda (see above) in having a robust dentary (Figure 7.10) with a deep subdental ditch throughout the medial side of the tooth row and a notch for the prearticular that extends anteriorly to the posterior one-third of the bone; a robust and well-waisted humerus 
(Figure 8.12) without thinning or ridging in the radial margin; and a twisted femur (Figure 8.13) with a flat flexor surface of the fibular condyle and a distally extending ridge at the trochanter.

\section{SPECIES COMPOSITION}

In the comparison based on $\mathrm{MNI}$, Rana ulma $(\mathrm{MNI}=49$, same hereafter), Odorrana narina (40), and Cynops ensicauda (20) were predominant elements in the Late Pleistocene assemblage at Minatogawa, while Babina holsti (2), Limnonectes namiyei (1), Buergeria japonica (1), Rhacophorus viridis viridis (1), and Echinotriton andersoni (1) were present in much lower proportions (Table).

In contrast, R. ulma (152) was the predominant element in the Late Pleistocene assemblage (lower unit) at Sashiki, accounting for nearly half of total amphibian $\mathrm{MNI}$ and more than $85 \%$ of anuran MNI. R. ulma was followed by newts (C. ensicauda [51] and E. andersoni [92]) and, in much lower proportions, the other anurans represented $(L$. namiyei [1], B. holsti [6], O. ishikawae [7], O. narina [5], and $R h$. viridis viridis [6]). The middle Holocene assemblage of the fissure (upper unit) had another distinct species composition comprised of only three anurans (Microhyla okinavensis [2], Bu. japonica [1], and $R h$. viridis viridis [1]) and $C$. ensicauda (1) with very few individuals documented (Table).

\section{DISCUSSION}

\section{Amphibian Fauna in the Late Pleistocene of Okinawajima}

Despite our investigation having included fossils from the same site (the Minatogawa Fissure), the Late Pleistocene amphibian fauna of Okinawajima shown in the present study differs markedly from that reported by Hasegawa (1980) (Table). Most notably, the fauna in the present study lacks any species extinct on the island, whereas Hasegawa (1980) reported two mainland Japanese frog species, Glandirana rugosa and Rana tagoi, from Minatogawa. Likewise, although Nokariya (1983b) suggested the fossil occurrence of a Southeast Asian rhacophorine frog (Polypedates leucomystax) on Minatogawa, all informative elements of the rhacophorine fossils investigated here are identified as the indigenous Rhacophorus viridis viridis.

The fossil records of Glandirana rugosa, Rana tagoi, and Polypedates leucomystax from Minatogawa (Hasegawa, 1980; Nokariya, 1983b; cited in Sanchiz, 1998) are attributed to misidentification.
Although the Minatogawa fossils discussed by Hasegawa (1980) and Nokariya (1983b) have never been reexamined, it is reasonable to assume that our detailed identification of the abundant fossils from the Minatogawa Fissure and an additional fissure may result in a more general taxonomic conclusion regarding the Okinawan Late Pleistocene amphibian fauna than those previous studies. As such, it is now apparent that the Late Pleistocene amphibian assemblages from the island do not support Hasegawa's (1980) paleogeographic hypothesis that assumes a Late Pleistocene continuous dry land connection between the Central Ryukyus and mainland Japan (see also Ota, 1998 and Kawana, 2002 for criticism of the hypothesis). Additionally, little doubt remains that $P$. leucomystax was artificially introduced to the Ryukyus in the mid-20th century (Kuramoto, 1965; Kuraishi et al., 2009).

The absence of the biogeographically aberrant frog Fejervarya kawamurai (see Introduction) in the fossils discussed here may be significant. While Hasegawa (1980) tentatively referred some of the Minatogawa fossils to this species (as Rana cf. limnocharis limnocharis), this record (the only fossil record of the species from the Central Ryukyus) is dubious, similar to certain extralimital species mentioned above. The species' Late Pleistocene oversea invasion of the Central Ryukyus was hypothesized by Toda et al. (1997) and Toda (1999) in an attempt to explain the species' exceptionally low genetic diversification among several conspecific populations of Japan and the Eurasian Continent. However, the present results suggest that the invasion of the Central Ryukyus may have taken place after the middle Holocene. Human involvement in the invasion is suspected owing to the synanthropic nature of the frog. If the Central Ryukyu population of this species has an artificial origin, the endemism of the Central Ryukyu amphibian fauna could be explained more logically. Additionally, the Hallowell's Tree Frog, Hyla hallowellii (a Central Ryukyus endemic hylid), is another exception of the extant "indigenous" amphibian species due to the absence of a fossil or archeological record from the island (it is therefore not listed in Table). Unlike F. kawamurai, however, some bones of this species have been found in putative Holocene deposits on Yoronjima Island of the Central Ryukyus (Nakamura et al., 2009). This species may thus have been confined to the northern part of the island, where it occurs presently (Maeda and Matsui, 1999). 


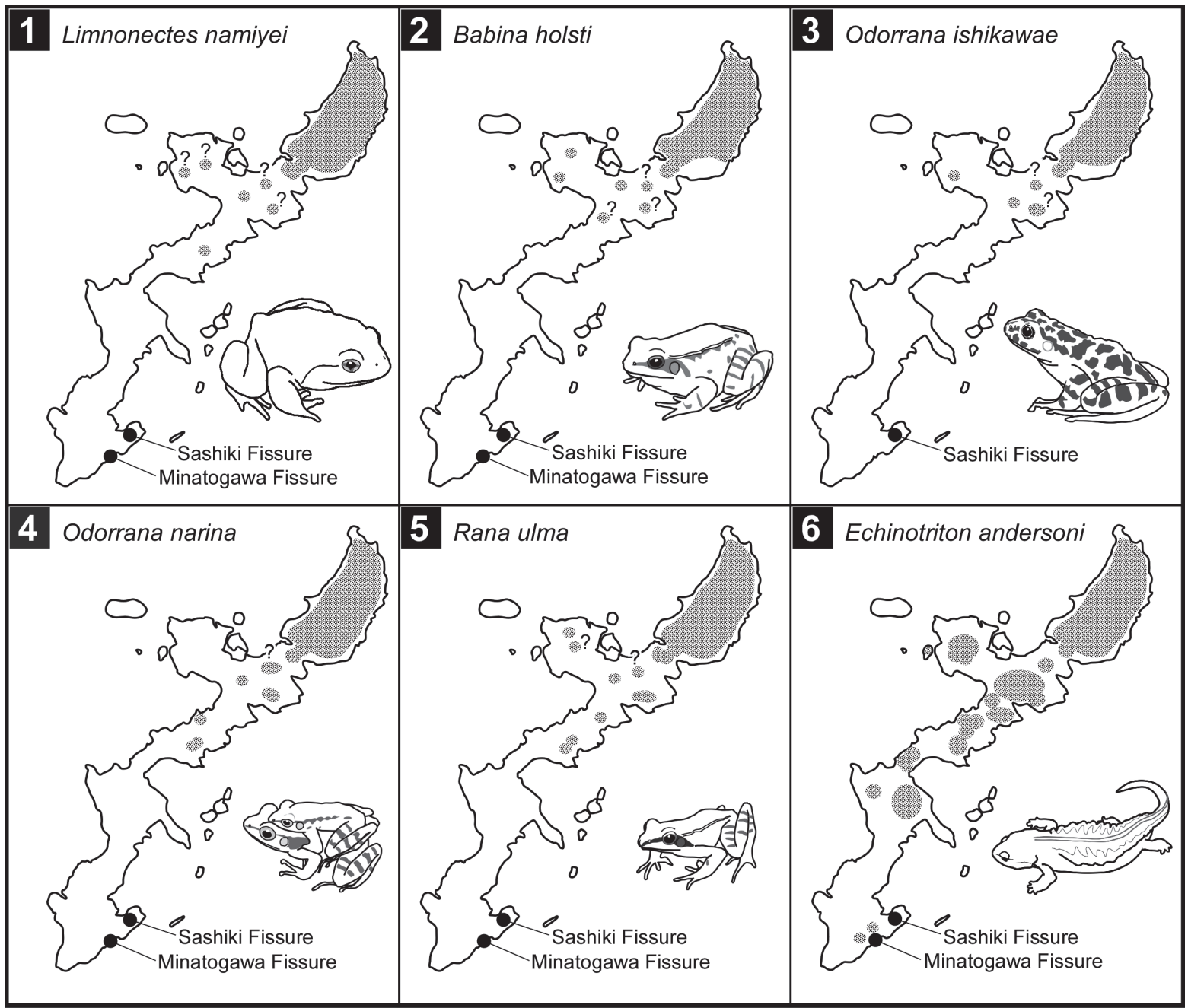

FIGURE 9. Maps showing current distributions (shaded areas) of five forest frogs (Limnonectes namiyeja, b, d, f-h, k, n [1], Babina holstia, b, d, f-k, m [2], Odorrana ishikawae a, b, d, f-h, j-l, o [3], O. narina $\mathrm{a}, \mathrm{b}, \mathrm{f}-\mathrm{h}$ [4], and Rana ulmaa, b, d, fk, o [5]) and the newt Echinotriton andersonia-j (6) on Okinawajima Island and adjacent islets. Superscripts after the species names indicate the data sources - a and b: Chigira (1977, 2003); c: Honda et al. (2012); d: Koba (1957); e: Matayoshi et al. (1977); f-h: Okinawa General Bureau, North Dam Construction Office (1997, 1998, 2002); i and j: Sato (1989, 1993); k: Tanaka (1993); I: Toyama (1988); m: Tominaga et al. (2014); n: Utsunomiya (1996b); and o: Y.N. personal observations at Oku. "?" denotes a population lacking a record or observation in the past 30 years.

\section{Local Paleoenvironment in the Late Quaternary}

As suggested by Hasegawa (1980), the Late Pleistocene amphibian fauna in the southern part of Okinawajima accommodated five obligate forest-dwellers (Limnonectes namiyei, Babina holsti, Odorrana ishikawae, O. narina, and Rana ulma), which are now strictly confined to the northern forested area of the island (Utsunomiya, 1995, 1996b; Toyama, 1996; Figure 9; note that $B$. holsti and $R$. ulma also occur on Tokashikijima and Kumejima Islands, respectively, of the Okinawa Island Group). This is suggestive of dense and humid vegetation, as found in the current northern for- ested area. This view is supported by the fossil occurrence of other forest vertebrates such as Tokudaia muenninki, Scolopax mira, and Gallirallus okinawae from some Late Pleistocene localities, including the Minatogawa Fissure, in the southern part of Okinawajima (Kawamura, 1989; Matsuoka, $2000,2003)$. Likewise, the substantive dominance of these frogs, mostly stream-breeders, in the fossil assemblages indicates the Late Pleistocene existence of stable surface stream systems (e.g., larvae of $B$. holsti and $O$. ishikawae often take more than one year to undergo metamorphosis: Utsunomiya, 1995; Toyama, 1996; Y.N. personal obser- 
vation). Their co-occurrence may also imply that there were headwaters diverse enough to secure habitat segregation for their larvae which are, as a rule, confined to headwaters and tend to occupy a species-specific microhabitat (Utsunomiya et al., 1983).

In contrast to the Minatogawa Fissure, which is located near a riverbank, the current vicinity of the Sashiki Fissure, which is situated on limestone beds that form the highest part of the southern part of the island, basically is devoid of surface freshwater habitats. Considering that today's few surface streams on the southern limestone area are derived solely from springs rising on the border between the water-permeable limestone and the underlying water-impermeable Shimajiri Group (Nishijima et al., 1974), a high subterranean-water level could be the most likely mechanism that maintained the inferred lotic habitats in the Late Pleistocene. This may be a consequence of a more pluvial climatic condition and/or much denser vegetation in the area than occurs today.

On the basis of fossil pollen records obtained from Izenajima Island, off the western coast of Okinawajima, Kuroda and Ozawa (1996) suggested that climatic conditions in the Last Glacial Maximum (LGM; 21 ka in common definition) of the Okinawa Island Group were much more arid than today, with much reduced broad-leaved evergreen forests. Their argument is based on the absence of pollen from several temperate (and thus extralimital) tree species such as Tsuga, Abies (Pinaceae), Alnus (Betulaceae), and the deciduous Quercus (Fagaceae), which "should have otherwise increased in the pollen proportion under cooler climate" (p. 338), as expected for the LGM. However, there is an unstated assumption here that the islands of the Central Ryukyus possessed an effective entryway for those trees from temperate climatic areas during the Late Pleistocene. In fact, the Late Pleistocene amphibian assemblages from the southern part of Okinawajima, which belong to the early (Sashiki [lower unit]) and the late (Minatogawa) stages of the LGM, do not support the occurrence of such arid conditions (see above). We believe that the absence of these trees in the Last Glacial Okinawan flora should simply be interpreted as caused by the consistent isolation of the Central Ryukyus from landmasses with temperate climate areas, such as mainland Japan.

The humid forests and lotic habitats on the southern part of the island may have mostly vanished by the middle Holocene, as the middle Holocene amphibian fauna from the Sashiki Fissure (upper unit) representing three frogs (Microhyla okinavensis, Buergeria japonica, and Rhacophorus viridis viridis) and one newt (Cynops ensicauda) is almost identical to the existing fauna on the southern part of the island (see Introduction). In addition, a Holocene fossil or archeological record of these forest frogs from the southern part of the island is lacking. The absence of Echinotriton andersoni in the Holocene sediments investigated here suggests that the species may have been highly localized in this part of the island (Figure 9.6).

A change in climate would have been the most probable cause of the inferred environmental alteration in the southern part of Okinawajima in the Late Pleistocene-middle Holocene. Nevertheless, the possibility that Paleolithic or Neolithic hunter-fisher-gatherers played a role in causing the change through deforestation or forest burning (e.g., Grayson, 2001; Kirch, 2005) cannot entirely be rejected. This is because human impact remains the least understood aspect of the terrestrial biotas in this archipelago while at the same time constituting a prime determinant of Holocene insular landscapes and biodiversities (Whittaker and Fernández-Palacios, 2007). To establish the cause of the Late Quaternary range collapse of these humid forest vertebrates on Okinawajima, well-dated and reasonably identified records of the Quaternary terrestrial vertebrates from the island and nearby areas should be expanded. Further investigation of the modern extirpations of these forest frogs (Figure 9) may also provide clues to explore the causal factor(s) of their prehistoric range reduction.

\section{ACKNOWLEDGMENTS}

We are grateful to M. Moriguchi (Okinawa University) for the provision of fossil specimens and discussion, to H.-M. Blain (IPHES, Spain) and an anonymous referee for careful review of an earlier version of the manuscript, and to $\mathrm{T}$. Johnson (Kyodo News Corp.) for verbal corrections. We also thank A. Takahashi (Okayama University of Science) for his help; N. Kidera (National Institute for Environmental Studies), Y. Misawa (Civil Engineering \& Eco-Technology Consultants Co. Ltd.), N. Murayama (Shinsei Shuppan Inc.), Y. Sawashi (Ministry of the Environment), N. Yoshikawa (NSMT), T. Komatsu, and T. Onishi (University of the Ryukyus) for providing part of the extant amphibian material; G. Masunaga (Saigendo), S. Matsumura, M. Toda, and A. Tominaga (University of the Ryukyus) for discussion and helpful comments; N. Shinzato, M. Takechi, and T. Tamaki 
(Yaese Town Museum of History and Folklore) for allowing us to examine the material from the Minatogawa Fissure; M. Toyama (Okinawa) and Z. Korsós (Hungarian Museum of Natural History, Hungary) for providing literature; and S. Kawada (NSMT), T. Sasaki (RUMF), and H. Otsuka (Kagoshima University Museum) for allowing us to examine extant anuran specimens under their care. Special thanks are due to Hyakuna Coral Co. Ltd. and nic Inc. (Nanjo City, Okinawa) for allowing us to investigate the Sashiki Fissure. This study was supported by a Grant-in-Aid to the 21st Century COE Program at the University of the Ryukyus from the Ministry of Education, Culture, Sports, Science and Technology, Japan (Monbu-KagakuSho).

\section{REFERENCES}

Anderson, J. 1871. A list of the reptilian accession to the Indian Museum, Calcutta from 1865 to 1870, with a description of some new species. Journal of the Asiatic Society of Bengal, 40:12-39.

Azuma, Y. 2007. Three new species of fossil terrestrial Mollusca from fissure deposits within the Ryukyu Limestone in Okinawa and Yoron Islands, Japan. Paleontological Research, 11:231-249.

Boettger, O. 1895. Neue Frösche und Schlangen von den Liukiu-Inseln. Zoologischer Anzeiger, 18:266270. (In German)

Bolkay, St.J. 1919. Osnove uporedne osteologije anurskih batrahija sa dodatkom o porijeklu Anura i sa skicom naravnoga sistema istih (Elements of the comparative osteology of the tailless batrachians. With an appendix on the probable origin of the anurous batrachians and a sketch of their natural system). Glasnik Zemaljskog Muzeja u Bosni i Hercegovini, 31:277-357. (In Croatian with English summary)

Bolkay, St.J. 1933. Atlas to work Dr. St. Bolkay: Elements of the comparative osteology of the tailless batrachians. With an appendix on the probable origin of the anurous batrachians and a sketch of their natural system. Zemaljski Muzej za Bosnu i Hercegovinu u Sarajevu, Sarajevo. (The plates of Bolkay, 1919 edited by R. Zaplata)

Boulenger, G.A. 1892. Descriptions of new reptiles and batrachians from the Loo Choo Islands. Annals and Magazines of Natural History; Zoology, Botany, and Geology, 6th Series, 10:302-304.

Cai, C. and Fei, L. 1984. Description of neotype of Echinotriton chinhaiensis (Chang) and its ecology and habit. Acta Herpetologica Sinica, 3:71-78, plate 9. (In Chinese with English abstract)

Channing, A. 1989. A re-evaluation of the phylogeny of Old World treefrogs. South African Journal of Zoology, 24:116-131.
Chigira, Y. 1977. Amphibians and reptiles, p. 129-179. In Nago City Board of Education (ed.), Reports on General Zoological Survey of Nago City, Nago City Natural Monuments Research Series 1. Nago City Board of Education, Nago. (In Japanese)

Chigira, Y. 2003. Amphibians of Nago City, p. 225-247. In Nago City Board of Education (ed.), Nature of Nago City, Reports on General Survey of Animals and Plants of Nago City 1998-2002, Nago City Natural Monuments Research Series 5. Nago City Board of Education, Nago. (In Japanese)

de Blainville, H.-M. 1816. Prodrome d'une nouvelle distribution systématique du règne animal. Bulletin des sciences par la Société philomathique de Paris, volume unknown:113-124. (In French)

Djong, H.T., Matsui, M., Kuramoto, M., Nishioka, M., and Sumida, M. 2011. A new species of the Fejervarya limnocharis Complex from Japan (Anura, Dicroglossidae). Zoological Science, 28:922-929.

Duellman, W.E. and Trueb, L. 1986. Biology of Amphibians. The Johns Hopkins University Press, Baltimore.

Duméril, A.M.C. and Bibron, G. 1841. Herpétologie Générale ou Histoire Naturelle Complète des Reptiles. Volume 8. Roret, Paris. (In French)

Estes, R. 1981. Encyclopedia of Paleoherpetology, Part 2: Gymnophiona, Caudata. Gustav Fischer Verlag, Stuttgart.

Fairbanks, R.G., Mortlock, R.A., Chiu, T.-C., Cao, L., Kaplan, A., Guilderson, T.P., Fairbanks, T.W., Bloom, A.L., Grootes, P.M., and Nadeau, M.-J. 2005. Radiocarbon calibration curve spanning 0 to 50,000 years BP based on paired ${ }^{230} \mathrm{Th} /{ }^{234} \mathrm{U} /{ }^{238} \mathrm{U}$ and ${ }^{14} \mathrm{C}$ dates on pristine corals. Quaternary Science Review, 24:1781-1796.

Fei, L., Ye, C., and Huang, Y. 1990. Key to Chinese Amphibia. Publishing House for Scientific and Technological Literature, Chongqing. (In Chinese)

Fischer von Waldheim, G. 1813. Zoognosia Tabulis Synopticis Illustrata, in Usum Prælectionum Academiæ Imperialis Medico-Chirurgicæ Mosquensis Edita (vol. 1). Nicolai S. Vsevolozsky, Moscow. (In Latin)

Fitzinger, L.J. 1843. Systema Reptilium. Fasciculus Primus. Braumüller und Seidel, Wien. (In Latin)

Frost, D.R. 2014. Amphibian Species of the World: an Online Reference. Version 6.0. American Museum of Natural History, New York. Cited at 23 July 2014. http://research.amnh.org/herpetology/amphibia/ index.html

Fujita, H. 1989. Stratigraphy and geologic structure of the pre-Neogene strata in the Central Ryukyu Islands. Journal of Science of the Hiroshima University, Series C (Geology and Mineralogy), 9:237-284.

Goldfuss, G.A. 1820. Handbuch der Zoologie. Zweite Abtheilung. Johann Leonhard Schrag, Nürnberg. (In German)

Grayson, D.K. 2001. The archaeological record of human impacts on animal populations. Journal of World Prehistory, 1:1-68. 
Günther, A.C.L.G. 1858. On the systematic arrangement of the tailless batrachians and the structure of Rhinophrynus dorsalis. Proceedings of the Zoological Society of London, 1858:339-352.

Hallowell, E. 1861 [“1860"]. Report upon the Reptilia of the North Pacific Exploring Expedition, under command of Capt. John Rogers, U. S. N. Proceedings of the Academy of Natural Sciences of Philadelphia, 12:480-509.

Hasegawa, Y. 1980. Notes on vertebrate fossils from Late Pleistocene to Holocene of Ryukyu Islands, Japan. The Quaternary Research (Daiyonki-Kenkyu), 18:263-267. (In Japanese with English abstract)

Hashimoto, M., Yahagi, K., Tsujimoto, Y., Saito, T., and Yoshida, K. 2002. Natural scientific surveys and analyses on the Minatogawa Fissure Site, p. 89-196. In Gushikami Village Board of Education (ed.), Minatogawa Fissure Site. Gushikami Village Board of Education, Gushikami. (In Japanese)

Hoffman, A.C. 1932. Researches relating to the validity of the South African Polypedatidae (Rhacophoridae) as an autonomous family of the Anura. South African Journal of Science, 29:562-583.

Honda, M., Matsui, M., Tominaga, A., Ota, H., and Tanaka, S. 2012. Phylogeny and biogeography of the Anderson's crocodile newt, Echinotriton andersoni (Amphibia: Caudata), as revealed by mitochondrial DNA sequences. Molecular Phylogenetics and Evolution, 65:642-653.

Kaifu, Y. and Fujita, M. 2012. Fossil record of early humans in East Asia. Quaternary International, 248:2-11.

Kawamura, Y. 1989. Quaternary rodent faunas in the Japanese Islands (part 2). Memoir of Faculty of Science, Kyoto University, Series Geology and Mineralogy, 54:1-235.

Kawana, T. 2002. Neotectonics in the Ryukyu Arc, p. 5983. In Kimura, M. (ed.), Establishment of the Ryukyu Arc and Colonization of Biota. Okinawa Times, Naha. (In Japanese)

Kirch, P.V. 2005. Archaeology and global change: The Holocene record. Annual Review of Environment and Resources, 30:409-440.

Kizaki, K. 1985. Central and northern parts of Okinawajima Island, p. 93-106. In Kizaki, K. (ed.), Geology of the Ryukyu Arc. Okinawa Times, Naha. (In Japanese)

Koba, K. 1957. Reptilia and Amphibia of Okinawa-jima of the Loo Choo Islands. Memoirs of the Faculty of Education, Kumamoto University, 5:191-208. (In Japanese)

Kuhl, H. and Van Hasselt, J.C. 1822. Uittreksels uit breieven van de Heeren Kuhl en Van Hasselt, aan de Heeren C. J. Temminck, Th. Van Swinderen en W. de Haan. Algemeene Konst-en Letter-Bode, 7:99-104. (In Dutch)
Kuraishi, N., Matsui, M., and Ota, H. 2009. Estimation of the origin of Polypedates leucomystax (Amphibia: Anura: Rhacophoridae) introduced to the Ryukyu Archipelago, Japan. Pacific Science, 63:317-325.

Kuramoto, M. 1965. A record of Rhacophorus leucomystax from the Ryukyu Islands. Bulletin of Fukuoka Gakugei University. Part 3, Natural Sciences, 15:5961.

Kuramoto, M., Satou, N., Oumi, S., Kurabayashi, A., and Sumida, M. 2011. Inter- and intra-island divergence in Odorrana ishikawae (Anura, Ranidae) of the Ryukyu Archipelago of Japan, with description of a new species. Zootaxa, 2767:25-40.

Kuroda, T. and Ozawa, T. 1996. Paleoclimatic and vegetational changes during the Pleistocene and Holocene in the Ryukyu Islands inferred from pollen assemblages. Chigaku Zasshi (Journal of Geography), 105:328-342. (In Japanese with English abstract)

Linnaeus, C. 1758. Systema Naturae per Regna Tria Naturae, Secundum Classes, Ordines, Genera, Species, cum Characteribus, Differentiis, Synonymis, Locis (10th edition, volume 1). L. Salvii, Stockholm. (In Latin)

Maeda, N. and Matsui, M. 1999. Frogs and Toads of Japan (revised edition). Bun-ichi Sogo Shuppan, Tokyo.

Maekado, A. 1989. Some physical and mechanical properties of the limestones in Okinawa Island. Bulletin of the Okinawa Geographical Society, 2:29-33.

Matayoshi, S., Oshiro, N., Kiyuna, T., Hoshikawa, H., Mitui, K., and Kumagai, E. 1977. A note on the distribution of Tylototriton andersoni Boulenger in Okinawa Island. Biological Magazine Okinawa, 15:1-4. (In Japanese)

Matsui, M. 2005. Geographic variation in amphibians, p. 63-77. In Masuda, R. and Abe, H. (eds.), Natural History of Zoogeography: Evolutionary Science in Distribution and Diversity. Hokkaido University Press, Sapporo. (In Japanese)

Matsui, M. 2007. Unmasking Rana okinavana Boettger, 1895 from the Ryukyus, Japan (Amphibia: Anura: Ranidae). Zoological Science, 24:199-204.

Matsui, M. 2011. On the brown frogs from the Ryukyu Archipelago, Japan, with descriptions of two new species (Amphibia, Anura). Current Herpetology, 30:111-128.

Matsui, M., Ito, H., Shimada, T., Ota, H., Saidapur, S.K., Khonsue, W., Tanaka-Ueno, T., and Wu, G.-F. 2005. Taxonomic relationships within the Pan-Oriental Narrow-mouth Toad Microhyla ornata as revealed by mtDNA analysis (Amphibia, Anura, Microhylidae). Zoological Science, 22:489-495.

Matsuoka, H. 2000. The Late Pleistocene fossil birds of the central and southern Ryukyu Islands, and their zoogeographical implications for the recent avifauna of the archipelago. Tropics, 10:165-188. 
Matsuoka, H. 2003. The intrinsic value of Yambaru mountainous forest of Okinawa, known by a paleontological research for the avifauna of Ryukyu Archipelago. Journal of Fossil Research, 36:60-67. (In Japanese)

Moriguchi, M. 2003. The School of Bone, volume 2. Wanderings in Okinawa Edition. Kodama-sha, Tokyo. (In Japanese)

Motokawa, M. 2009. Distribution patterns and zoogeography of Japanese mammals, p. 44-46. In Ohdachi, S.D., Ishibashi, Y., Iwasa, M.A., and Saitoh, T. (eds.), Wild Mammals of Japan. Shoukadoh, Kyoto.

Nakamura, Y., Takahashi, A., and Ota, H. 2009. Evidence for the recent disappearance of the Okinawan Tree Frog Rhacophorus viridis on Yoronjima Island of the Ryukyu Archipelago, Japan. Current Herpetology, 28:29-33.

Naruse, T., Karasawa, H., Shokita, S., Tanaka, T., and Moriguchi, M. 2004. A first fossil record of the terrestrial crab, Geothelphusa tenuimanus (Miyake and Minei, 1965) (Decapoda, Brachyura, Potamidae) from Okinawa Island, Central Ryukyus, Japan. Crustaceana, 76:1211-1218.

Nishijima, S., Shokita, S., and Kawanabe, H. 1974. A general description of the streams of the Ryukyu Islands. Ecological Studies of Nature and Conservation of the Ryukyu Islands, 1:113-143. (In Japanese)

Nohara, T. and Irei, S. 2002. Animal remains from the Minatogawa Fissure Site, p. 29-87. In Gushikami Village Board of Education (ed.), Minatogawa Fissure Site. Gushikami Village Board of Education, Gushikami. (In Japanese)

Nokariya, H. 1983a. Comparative osteology of Japanese frogs and toads for paleontological studies (I): Bufo, Hyla, Microhyla and Bombina. Bulletin of the National Science Museum, Tokyo, Ser. C, 9:23-40.

Nokariya, H. 1983b. Comparative osteology of Japanese frogs and toads for paleontological studies (II): Rhacophorus. Bulletin of the National Science Museum, Tokyo, Ser. C, 9:137-149.

Nokariya, H. 1984. Comparative osteology of Japanese frogs and toads for paleontological studies (III): Rana. Bulletin of the National Science Museum, Tokyo, Ser. C, 10:55-79.

Nokariya, H. and Hasegawa, Y. 1979. Osteological study of the Japanese anurans, p. 275-311. In le Village Board of Education (ed.), Nagarabaru-Nishi Shell Mound: Survey Report on Urgent Excavation, Edition of Natural Remains. le Village Board of Education, le. (In Japanese)

Nussbaum, R.A. and Brodie, E.D. 1982. Partitioning of the Salamandrid genus Tylototriton Anderson (Amphibia: Caudata) with a description of a new genus. Herpetologica, 38:320-332.

Okada, Y. and Koba, K. 1931. Discussion on the distribution of animals in Japan. Zoological Magazine (Tokyo), 43:320-351. (In Japanese)
Okinawa General Bureau, North Dam Construction Office. 1997. Data for Biological and Environmental Surveys at the Proposed Localities for the Disposal of the Soil Associated with the Construction of the Taiho Dam. Okinawa Construction Welfare Association, Urasoe. (In Japanese)

Okinawa General Bureau, North Dam Construction Office. 1998. Data for Biological and Environmental Survey in Taiho River. Okinawa Construction Welfare Association, Urasoe. (In Japanese)

Okinawa General Bureau, North Dam Construction Office. 2002. Data for Biological Survey in the Northern Part of Okinawajima Island. Vol. 2. Edition of Mammals, Birds, Reptiles, Amphibians, and Terrestrial Insects. Okinawa Construction Welfare Association, Urasoe. (In Japanese)

Ota, H. 1998. Geographic patterns of endemism and speciation in amphibians and reptiles of the Ryukyu Archipelago, Japan, with special reference to their paleogeographic implications. Researches on Population Ecology, 40:189-204.

Ota, H. 2003. Toward a synthesis of paleontological and neontological information on the terrestrial vertebrates of the Ryukyu Archipelago. I. Systematics and biogeographic review. Journal of Fossil Research, 36:43-59.

Rafinesque, C.S. 1814. Fine del Prodromo d'erpetologia siciliana. Specchio delle Scienze o Giornale Enciclopedico di Sicilia, 2:102-104. (In Italian)

Sagae, K., Humblet, M., Odawara, K., Chiyonobu, S., Sato, T., Kabamoto, J., Takayanagi, H., and Iryu, Y. 2012. Stratigraphy of the Ryukyu Group in southern Okinawa-jima, Ryukyu Islands, Japan. Journal of the Geological Society of Japan, 118:117-136. (In Japanese with English abstract)

Sanchiz, B. 1998. Encyclopedia of Paleoherpetology, Part 4: Salientia. Verlag Dr. Friedrich Pfeil, München.

Sato, F. 1989. On Animals of Motobu Town and the state of natural environment of the town. Bulletin of the Motobu Museum, 3:16-131. (In Japanese)

Sato, F. 1993. On the state of natural environment of Motobu Town and small animals occurring in Castanopsis sieboldii forests, p. 32-182. In Motobu Town Board of Education (ed.), General Survey of Animals and Plants of Motobu Town, Interim Reports of Faunal Surveys. Motobu Town Board of Education, Motobu. (In Japanese)

Sekiya, K., Miura, I., and Ogata, M. 2012. A new frog species of the genus Rugosa from Sado Island, Japan (Anura, Ranidae). Zootaxa, 3575:49-62.

Stejneger, L. 1901. Diagnoses of eight new batrachians and reptiles from the Riu Kiu Archipelago, Japan. Proceedings of the Biological Society of Washington, 14:189-191.

Tachihara, K. 2003. The environment and biota of inland waters in the Ryukyu Islands, p. 33-41. In Nishida, M., Shikatani, N., and Shokita, S. (eds.), The Flora and Fauna of Inland Waters in the Ryukyu Islands. Tokai University Press, Tokyo. (In Japanese) 
Tanaka, S. 1993. The state of amphibians and reptiles of Motobu Town (an interim report), p. 22-31. In Motobu Town Board of Education (ed.), General Survey of Animals and Plants of Motobu Town, Interim Reports of Faunal Surveys. Motobu Town Board of Education, Motobu. (In Japanese)

Thompson, J.C. 1912. Prodrome of a description of a new genus of Ranidae from the Loo Choo Islands. Herpetological Notices (no. 1). Author's Private Publication.

Toda, M. 1999. Historical biogeography of East Asian population of Rana limnocharis (Amphibia: Anura): A review, p. 299-315. In Ota, H. (ed.), Tropical Island Herpetofauna: Origin, Current Diversity, and Conservation. Elsevier Science B. V., Amsterdam.

Toda, M., Nishida, M., Matsui, M., Wu, G.-F., and Ota, H. 1997. Allozyme variation among East Asian populations of the Indian rice frog, Rana limnocharis (Amphibia: Anura). Biochemical Systematics and Ecology, 25:143-159.

Tominaga, A., Matsui, M., and Nakata, K. 2014. Genetic diversity and differentiation of the Ryukyu endemic frog Babina holsti as revealed by mitochondrial DNA. Zoological Science, 31:64-70.

Toyama, M. 1988. Distributional information for animals of natural monument (Preliminary edition), p. 215248. In Okinawa Prefectural Board of Education (ed.), Urgent Survey of the Natural Monuments in Kunigami District, III. Okinawa Prefectural Board of Education, Naha. (In Japanese)

Toyama, M. 1996. Holst's Frog, p. 257-261. In Japan Association for Fishery Resources Conservation (ed.), Fundamental Information on Valuable Wild Aquatic Animals of Japan (III). Japan Association for Fishery Resources Conservation, Tokyo. (In Japanese)

Tschudi, J.J.v. 1838. Classification der Batrachier mit Berücksichtigung der fossilen Thiere dieser Abtheilung der Reptilien. Petitpierre, Neuchâtel. (In German)
Tsuchi, R. 1982. Geology of southern Okinawa Island, with reference to the formation of the Minatogawa Fissure, p. 197-204. In Suzuki, H. and Hanihara, K. (eds.), The Minatogawa Man: The Upper Pleistocene Man from the Island of Okinawa. The University Museum, the University of Tokyo, Bulletin 19. University of Tokyo Press, Tokyo.

Utsunomiya, T. 1995. Ishikawa's Frog, p. 429-434. In Japan Association for Fishery Resources Conservation (ed.), Fundamental Information on Valuable Wild Aquatic Animals of Japan (II). Japan Association for Fishery Resources Conservation, Tokyo. (In Japanese)

Utsunomiya, T. 1996a. Anderson's Crocodile Newt, p. 250-256. In Japan Association for Fishery Resources Conservation (ed.), Fundamental Information on Valuable Wild Aquatic Animals of Japan (III). Japan Association for Fishery Resources Conservation, Tokyo. (In Japanese)

Utsunomiya, T. 1996b. Namiye's Frog, p. 268-272. In Japan Association for Fishery Resources Conservation (ed.), Fundamental Information on Valuable Wild Aquatic Animals of Japan (III). Japan Association for Fishery Resources Conservation, Tokyo. (In Japanese)

Utsunomiya, Y., Utsunomiya, T., Katsuren, S., and Toyama, M. 1983. Habitat segregation observed in the breeding of five frog species dwelling in a mountain stream of Okinawa Island. Annotationes Zoologicae Japonenses, 56:149-153.

Venczel, M. 1999. Land salamanders of the family Hynobiidae from the Neogene and Quaternary of Europe. Amphibia-Reptilia, 20:401-412.

Whittaker, R.J. and Fernández-Palacios, J.M. 2007. Island Biogeography: Ecology, Evolution and Conservation (Second Edition). Oxford University Press, Oxford. 


\section{APPENDIX}

List of comparative skeletal specimens examined (including partially skeletonized specimens). Institutional and collection abbreviations are as follows: collection number of University Museum of the Kagoshima University, Kagoshima, Japan (OT, IK, HT); Kyoto University Museum Zoological collection, Kyoto University, Kyoto, Japan (KUZ); Yasuyuki Nakamura private collection (NPN); and National Science Museum Tokyo collection, Tokyo, Japan (NSMT).

ANURA

Bombinatoridae

Bombina orientalis: NPN 178, 179, Gangwong-do, South Korea (one male and one female).

Bufonidae

Bufo bankorensis: NPN 105, Yilan Co., Taiwan; NPN 106-110, Wulai, Taipei Co., Taiwan (two males and four females).

Bufo gargarizans miyakonis: NPN 097, 098, four un-catalogued specimens, Miyakojima Is., Okinawa Pref., Japan (four males and two females).

Bufo japonicus formosus: NPN 065, 066, 068, 069, Kanagawa Pref., Japan (three males and one female).

Bufo japonicus japonicus: NPN 082-084, 089, 090, Kagoshima Pref., Japan (three males and two females).

Bufo torrenticola: NPN 070-072, 076, 077, Nara Pref., Japan (three males and two females).

Duttaphrynus melanostictus: NPN 100, 101, Keelung, Taiwan; NPN 099, Taoyuan Co., Taiwan; NPN 102, Ranong, Thailand (two males and two females).

Hylidae

Hyla japonica: KUZ R56877, Nagano Prf., Japan; NPN 664, 665, Oita Prf., Japan; NPN 1109, Shizuoka Prf., Japan (one male and three females).

Hyla hallowellii: NPN 308, 309, 311, 312, Okinawajima Is., Okinawa Prf., Japan (two males and two females).

\section{Dicroglossidae}

Fejervarya kawamurai: NPN 030-034, 1127, 1128, 1134, 1135, Okinawajima Is., Okinawa Prf., Japan; KUZ R56879, R56880, Wakayama Prf., Japan (four males and seven females).

Fejervarya sakishimensis: NPN 114, 116, 117, Ishigakijima Is., Okinawa Prf., Japan (one male and two females).

Limnonectes fujianensis: NPN 325, 327, Taipei Co., Taiwan (one male and one female).
Limnonectes namiyei: KUZ R65738, R71534, R72180, R72422, R72423, Okinawajima Is., Okinawa Prf., Japan (two males and three females).

\section{Ranidae}

Babina holsti: KUZ R62704, R62978, R72031, NSMT 00855, Okinawajima Is., Okinawa Prf., Japan (three males and one female).

Babina subaspera: OT-880815-01, OT-940723-03, OT-940723-04, OT-940725-06, OT940726-07, KUZ R28159, Amamioshima Is., Kagoshima Prf., Japan (two males and four females).

Glandirana emeljanovi: NPN 192, 193, Gangwongdo, South Korea (two females).

Glandirana rugosa: KUZ R56881, R 56882, R56884, Wakayama Prf., Japan; NPN 046, 047, 722-725, Oita Prf., Japan (four males and five females).

Hylarana guentheri: KUZ R38877, Matsu Is., Taiwan (one female).

Hylarana latouchii: NPN 160, 164, Taipei Co., Taiwan (one male and one female).

Lithobates catesbeianus: NPN 1012, Okinawajima Is., Okinawa Prf., Japan; NPN 1122, Iheyajima Is., Okinawa Prf., Japan (two males).

Nidirana adenopleura: NPN 155, 156, Taipei Co., Taiwan (one male and one female).

Nidirana (or Babina) okinavana: NPN 125, 126, 128, 131, Ishigakijima Is., Okinawa Prf., Japan (two males and two females).

Odorrana amamiensis: NPN 132, 133, 135, 136, 294, Amamioshima Is., Kagoshima Prf., Japan (three males and two females).

Odorrana ishikawae: KUZ R57893, R62749, R65737, Okinawajima Is., Okinawa Prf., Japan (two males and one female).

Odorrana splendida: KUZ R28147, R28155, R28156, R28159, Amamioshima Is., Kagoshima Prf., Japan (two males and two females).

Odorrana narina: NPN 003, 014-018, 269, 271, 276-278, 284, 372-376, Okinawajima Is., Okinawa Prf., Japan (nine males and eight females). 
Odorrana supranarina: NPN 355-358, 360, 361, Ishigakijima Is., Okinawa Prf., Japan (three males and three females).

Odorrana utsunomiyaorum: KUZ R62289, Ishigakijima Is., Okinawa Prf., Japan; KUZ R62458, R62459, R62461, Iriomotejima Is., Okinawa Prf., Japan (two males and two females).

Pelophylax nigromaculatus: KUZ R56872, R56874, NPN 662, 663, Nagano Prf., Japan; NPN 667-670, Oita Prf., Japan; NPN 813, 814, Nara Prf., Japan (three males and seven females).

Pelophylax porosus porosus: NPN 211, 214, 216, 217, Nagano Prf., Japan (two males and two females).

Pelophylax porosus brevipodus: NPN 049-055, Nagano Prf., Japan; NPN 1114, 1116, Shiga Prf., Japan (three males and five females).

Rana dybowskii: NPN 245-247, 249, Tsushima Is., Nagasaki Prf., Japan (two males and two femals).

Rana huanrensis: NPN 170, Gangwong-do, South Korea (one male).

Rana japonica: NPN 330-332, 044, 045, 661, 666, Oita Prf., Japan (three males and four females).

Rana kobai: NPN 827, 828, Kakeromajima Is., Kagoshima Prf., Japan; NPN 1106-1108, 1111, Amamioshima Is., Kagoshima Prf., Japan (four males and two females).

Rana longicrus: KUHE 50594, Taipei Co., Taiwan (one female).

Rana ornativentris: KUZ R56888, R56889, Nagano Prf., Japan; NPN 321, 322, 324, Kanagawa Prf., Japan (two males and three females).

Rana pirica: NPN 316, 317, Hokkaido Prf., Japan (one male and one female).

Rana sakuraii: NPN 336-339, Kanagawa Prf., Japan (two males and two females).

Rana sauteri: KUHE 50596, Tainan, Taiwan (one female).

Rana tagoi tagoi: KUZ R56878, Hyogo Prf., Japan; NPN 021, 022, 048, 334, 335, 342-344, Kanagawa Prf., Japan; NPN 1113, Nagano Prf., Japan; NPN 1123, 1124, Nara Prf., Japan (five males and seven females).
Rana tsushimensis: NPN 297-302, Tsushima Is., Nagasaki Prf., Japan (three males and three females).

Rana ulma: NPN 001, 002, 006, 008, 010-012, 023, 112, 119, 121, 122, 243, Okinawajima Is., Okinawa Prf., Japan (six males and seven females).

\section{Microhylidae}

Microhyla okinavensis: NPN 035-038, 1136-1139, Okinawajima Is., Okinawa Prf., Japan (three males and five females).

Rhacophoridae

Buergeria buergeri: KUZ R56887, Wakayama Prf., Japan; NPN 345, 346, 353, Oita Prf., Japan (two males and two females).

Buergeria japonica: NPN 024, 026-029, 1131 , 1132, Okinawajima Is., Okinawa Prf., Japan (three males and four females).

Buergeria robusta: NPN 146, 550, Taipei Co., Taiwan (one male and one female).

Polypedates leucomystax: NPN 019, 020, 042, $043,1125,1126,1129,1130,1133$, Okinawajima Is., Okinawa Prf., Japan (three males and six females).

Rhacophorus arboreus: NPN 204, 205, Kanagawa Prf., Japan (two males).

Rhacophorus schlegelii: NPN 079, Nara Prf., Japan; NPN 196, 203, Shizuoka Prf., Japan (one male and two females).

Rhacophorus owstoni: NPN 113, 320, 387, Iriomotejima Is., Okinawa Prf., Japan (two males and one female).

Rhacophorus viridis amamiensis: NPN 136, 137, 139, Amamioshima Is., Kagoshima Prf., Japan (two males and one female).

Rhacophorus viridis viridis: NPN 004, 005, 039, 040, 222, 225-227, 367, 371, Okinawajima Is., Okinawa Prf., Japan (five males and five females).

Kurixalus eiffingeri: NPN 319, Ishigakijima Is., Okinawa Prf., Japan; NPN 318, Iriomotejima Is., Okinawa Prf., Japan (one male and one female).

\section{CAUDATA \\ Hynobiidae}

Hynobius nigrescens: NPN 1140, Locality and gender unknown.

Hynobius lichenatus: NPN 1141, Locality and gender unknown. 


\section{Salamandridae}

Cynops ensicauda: NPN 025, 314, 315, Okinawajima Is., Okinawa Prf., Japan (one male and two females).
Cynops pyrrhogaster. NPN 303, 304, Kagoshima Prf., Japan (one male and one female).

Echinotriton andersoni: KUZ R72424, R72425, Okinawajima Is., Okinawa Prf., Japan (two females). 